Article

\title{
Human Cytomegalovirus Nuclear Capsids Associate with the Core Nuclear Egress Complex and the Viral Protein Kinase pUL97
}

\author{
Jens Milbradt 1,* (D), Eric Sonntag ${ }^{1}$, Sabrina Wagner ${ }^{1}$, Hanife Strojan ${ }^{1}$, Christina Wangen ${ }^{1}$, \\ Tihana Lenac Rovis ${ }^{2}$, Berislav Lisnic ${ }^{2}$, Stipan Jonjic ${ }^{2}$, Heinrich Sticht ${ }^{3}$ (D), William J. Britt ${ }^{4}$ (D), \\ Ursula Schlötzer-Schrehardt ${ }^{5}$ and Manfred Marschall ${ }^{1, *}$ \\ 1 Institute for Clinical and Molecular Virology, Friedrich-Alexander University of Erlangen-Nürnberg, \\ Erlangen 91054, Germany; eric.sonntag@uk-erlangen.de (E.S.); sabrina.wagner@uk-erlangen.de (S.W.); \\ hanife.strojan@web.de (H.S.); christina.wangen@uk-erlangen.de (C.W.) \\ 2 Department of Histology and Embryology, Faculty of Medicine, University of Rijeka, Rijeka 51000, Croatia; \\ tihana.lenac@medri.uniri.hr (T.L.R.); berislav.lisnic@medri.uniri.hr (B.L.); stipan.jonjic@medri.uniri.hr (S.J.) \\ 3 Division of Bioinformatics, Institute of Biochemistry, Friedrich-Alexander University of Erlangen-Nürnberg, \\ Erlangen 91054, Germany; heinrich.sticht@fau.de \\ 4 Departments of Pediatrics and Microbiology, School of Medicine, University of Alabama at Birmingham, \\ Birmingham, AL 35294, USA; wbritt@uab.edu \\ 5 Department of Ophthalmology, University Medical Center Erlangen, Erlangen 91054, Germany; \\ ursula.schloetzer-schrehardt@uk-erlangen.de \\ * Correspondence: jens.milbradt@fau.de (J.M.); manfred.marschall@fau.de (M.M.); \\ Tel.: +49-913-1853-6480 (J.M.); +49-913-1852-6089 (M.M.)
}

Received: 19 December 2017; Accepted: 10 January 2018; Published: 13 January 2018

\begin{abstract}
The nuclear phase of herpesvirus replication is regulated through the formation of regulatory multi-component protein complexes. Viral genomic replication is followed by nuclear capsid assembly, DNA encapsidation and nuclear egress. The latter has been studied intensely pointing to the formation of a viral core nuclear egress complex (NEC) that recruits a multimeric assembly of viral and cellular factors for the reorganization of the nuclear envelope. To date, the mechanism of the association of human cytomegalovirus (HCMV) capsids with the NEC, which in turn initiates the specific steps of nuclear capsid budding, remains undefined. Here, we provide electron microscopy-based data demonstrating the association of both nuclear capsids and NEC proteins at nuclear lamina budding sites. Specifically, immunogold labelling of the core NEC constituent pUL53 and NEC-associated viral kinase pUL97 suggested an intranuclear NEC-capsid interaction. Staining patterns with phospho-specific lamin A/C antibodies are compatible with earlier postulates of targeted capsid egress at lamina-depleted areas. Important data were provided by co-immunoprecipitation and in vitro kinase analyses using lysates from HCMV-infected cells, nuclear fractions, or infectious virions. Data strongly suggest that nuclear capsids interact with pUL53 and pUL97. Combined, the findings support a refined concept of HCMV nuclear trafficking and NEC-capsid interaction.
\end{abstract}

Keywords: herpesviral nuclear egress; nuclear egress complex (NEC); viral protein kinase pUL97; immunogold-electron microscopy; NEC-capsid interaction; human cytomegalovirus

\section{Introduction}

Human cytomegalovirus (HCMV, family Herpesviridae) represents a major, worldwide-distributed human pathogen. Primary HCMV infection of the immunocompetent host frequently remains asymptomatic but severe disease can occur upon infection of immunonaïve and immunocompromised 
individuals, such as neonates, transplant recipients and cancer or AIDS patients [1]. HCMV pathogenicity is often directly linked with the efficiency of viral replication and both events are substantially determined by the balance of virus-host interaction [2]. In this regard, prominent examples of protein-protein interactions have been described including the formation of viral-cellular multiprotein complexes [3-7].

The fine-regulated process of herpesviral nuclear egress is a primary obstacle for the transition of nucleocapsids through the nuclear envelope and represents a rate-limiting step of viral replication efficiency. Nuclear egress is not mediated by passage through the nuclear pore complex (NPC) due to limitations in size (reviewed by [8-15]). Instead, a non-canonical pathway has been described on the basis of nuclear lamina distortion, primary envelopment at the inner nuclear membrane and a subsequent sequence of cytoplasmic steps including de-envelopment/re-envelopment and virion maturation. Important molecular details of how nuclear capsid egress through the nuclear envelope is achieved have been mechanistically elucidated recently for HCMV and other herpesviruses (reviewed by [11,12,15-17]).

As an initial step, HCMV pUL50 and pUL53 form a core nuclear egress complex (NEC) by heterodimerization at the nuclear rim, before they recruit further viral and cellular proteins. The main constituents of the HCMV-specific multi-component NEC, as determined by protein interaction studies particularly including proteomic analyses ([3] and references therein), are pUL97, p32/gC1qR, emerin, protein kinase $\mathrm{C}(\mathrm{PKC})$ and additional proteins. Among these, pUL97 is of particular importance, since its kinase activity is primarily responsible for nuclear lamina disassembly during the late phase of HCMV replication. Earlier studies showed the NEC association of pUL97 is mostly mediated in an indirect way through p32/gC1qR binding, thus bridging pUL97 to the pUL50-pUL53 core NEC [18]. In addition, cellular protein kinases were found NEC-associated, in particular, PKC and cyclin-dependent kinase 1 (CDK1), as identified by pUL50-specific co-immunoprecipitation $[19,20]$. Concerning the association of nuclear HCMV capsids with the NEC, however, the mechanism remained widely undefined to date. A number of capsid proteins have been discussed as possible candidates for mediating the contact with the NEC including major capsid protein (MCP) and smallest capsid protein (SCP) [21-24]. In addition, a number of further candidates are conceivable, such as the capsid portal protein, the capsid vertex-specific complex (CVSC), or other known capsid components (Table 1; references a: [25-37]; b: [15,38-47]; c: [48-51]). So far, it remains unclear whether the core NEC proteins themselves mediate capsid contacts or whether further proteins of the multi-component NEC may be involved. In any case, the current state of the art strongly suggests a docking of HCMV capsids to distinct sites of the nuclear envelope, termed as lamina-depleted areas (LDAs) [52-54]. The transition through these sites is characterized by the capsid budding within large inner nuclear membrane (INM) invaginations resulting in primary envelopment into the perinuclear space.

Table 1. Herpesviral nuclear capsid-associated proteins.

\begin{tabular}{cccc}
\hline Type of Protein & $\begin{array}{c}\text { Alpha-Herpesvirus }^{\text {a }} \\
\text { HSV-1 }\end{array}$ & $\begin{array}{c}\text { Beta-Herpesvirus }^{\mathbf{b}} \\
\text { HCMV }\end{array}$ & $\begin{array}{c}\text { Gamma-Herpesvirus }^{\mathbf{c}} \\
\text { EBV }\end{array}$ \\
\hline Capsid portal & pUL6 & pUL104 & BBRF1 \\
Capsid scaffolding & pUL26.5 & pUL80.5/pUL80a & BdRF1 \\
CVSC & pUL17 & pUL93 & BGLF1 \\
& pUL25 & pUL77 & BVRF1 \\
Terminase complex & pUL36 & nd & nd \\
& pUL15 & pUL89 & BGRF1/BDRF1 \\
pUL28 & pUL56 & BALF3 \\
Cleavage-packaging & pUL33 & pUL51 & BFRF1A \\
NEC core protein & pUL32 & pUL52 & BFLF1 $d$ \\
Protein kinase & pUL31 & pUL53 & nd \\
\hline
\end{tabular}

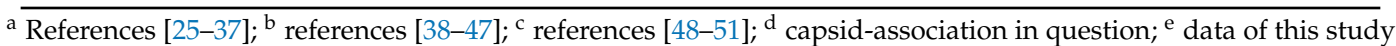
and references $[3,15] ;$ nd, not determined. 
As LDAs appear to represent the preferred sites of HCMV nuclear capsid egress, the mode of specific rearrangement of the nuclear lamina in a locally restricted manner has recently attracted major interest of researchers and particularly lamina phosphorylation could be defined as an initial molecular trigger (reviewed by [55]). The site-specific phosphorylation of lamins, primarily effected by HCMV protein kinase pUL97, leads to a destabilization of the nuclear lamina. According to the current view, this process is not only induced by lamin phosphorylation but also subsequent phosphorylation-dependent regulatory events, such as proline cis/trans isomerization [56]. Very recently, we and others described the functional and structural properties of herpesviral egress proteins, i.e., the essential and conserved core NEC formed by pUL50 and pUL53 in the case of HCMV ([15] and references therein). A general hallmark of herpesviral core NECs is their specific recruitment of further NEC-associated proteins, which in part are identical, in other parts, however, differ between individual herpesviruses [3,5,15]. Importantly, the herpesviral multi-component NEC has at least three different functional properties, i.e., (i) the reorganization of the nuclear lamina through the activity of recruited effector proteins; (ii) the inner nuclear membrane interaction to initiate viral budding processes; and (iii) the postulated docking of NEC proteins to viral nuclear capsids (reviewed by $[11,15,17])$. In this report, we investigated the association of nuclear HCMV capsids with NEC proteins and budding sites at the nuclear lamina. Specifically, we provide evidence that the HCMV core NEC, especially its constituent pUL53, may directly associate with virions and, moreover, that the viral nuclear protein kinase pUL97 is found associated with the core NEC. The findings support a refined concept of the nuclear role of the HCMV-produced NEC, in particular by facilitating the targeting of capsids to nuclear envelope budding sites.

\section{Materials and Methods}

\subsection{Cell Culture and HCMV Infection}

Primary human foreskin fibroblasts (HFFs) were cultivated in minimal essential medium (Thermo Fisher Scientific, Waltham, MA, USA) containing 7.5\% foetal calf serum, $350 \mu \mathrm{g}$ glutamine per $\mathrm{mL}$ and $100 \mu \mathrm{g}$ gentamicin per mL. For infection experiments, HFFs (passage no. 10-15) were plated in 6-well plates or $175 \mathrm{~cm}^{2}$ cell culture flasks at a density of $3.2 \times 10^{5}$ cells per well or $2-3 \times 10^{6}$ cells per flask, respectively. One day later, HFFs were infected with either HCMV strain AD169 or recombinant HCMV strain AD169-GFP at multiplicities of infection (MOI) between 1.0 and 2.0 as previously described [57].

\subsection{Antibodies}

A description of the antibodies used in this study, i.e., for the various techniques of Western blot (WB), immunoprecipitation (IP), in vitro kinase assay (IVKA), immunogold labelling in electron microscopy (IEM), or further applications, is provided by Table $2[3,6,19,20,22,24,56,58-76]$.

\subsection{Immunogold Labelling and Transmission Electron Microscopy (TEM)}

HFFs, plated on permanox coverslips (Thermo Fisher Scientific), were infected with HCMV strain AD169 at a MOI of 2.0. At $72 \mathrm{~h}$ post-infection (hpi), cells were fixed with $4 \%$ paraformaldehyde and $0.1 \%$ glutaraldehyde in $0.1 \mathrm{M}$ cacodylate buffer ( $\mathrm{pH} 7.4$ ) for $10 \mathrm{~min}$ at room temperature. Cells were sectioned by using an ultramicrotome (Ultracut E; Leica Microsystems, Wetzlar, Germany). The thickness of sections to be further analysed was 30 to $40 \mathrm{~nm}$. For post-embedding immunogold labelling, fixed cells were rinsed in buffer, dehydrated serially to $70 \%$ ethanol at $-20{ }^{\circ} \mathrm{C}$ and embedded in LRWhite resin (Electron Microscopy Sciences, Hatfield, PA, USA). Ultrathin sections were successively incubated in Tris-buffered saline (TBS), $0.05 \mathrm{M}$ glycine in TBS, $0.5 \%$ ovalbumin and $0.5 \%$ fish gelatine in TBS, primary antibodies diluted in TBS-ovalbumin overnight at $4{ }^{\circ} \mathrm{C}$ and finally in $10 \mathrm{~nm}$ gold-conjugated secondary antibodies (Biocell, Cardiff, UK) diluted 1:30 in TBS-ovalbumin for $1 \mathrm{~h}$. Primary antibodies included: rabbit monoclonal antibody (mAb)-Lamin A/C (EPR4100; Abcam plc, Cambridge, UK; 1:30 dilution in PBS), rabbit polyclonal antibody (pAb)-pS22-lamin 
A/C (Cell Signaling Technology, Danvers, MA, USA; 1:5 dilution), rabbit pAb-UL97 (Boston, kindly provided by Dr. D. Coen, Boston, MA, USA; 1:1000) and mouse pAb-UL53 (Bologna, kindly provided by Dr. P. Dal Monte, Bologna, Italy; 1:200). After rinsing, sections were stained with uranyl acetate and examined with a transmission electron microscope (906E, Zeiss Microscopy, Oberkochen, Germany). For each antibody staining, the numbers of analysed sections were five to ten (each carrying approx. 50 cells) and numbers of capsid clusters were between one to five per infected cell nucleus. In negative control experiments, the primary antibody was replaced by PBS or equimolar concentrations of nonimmune rabbit IgG or an irrelevant primary antibody.

Table 2. Basic characteristics and specific reactivities of antibodies used in this study.

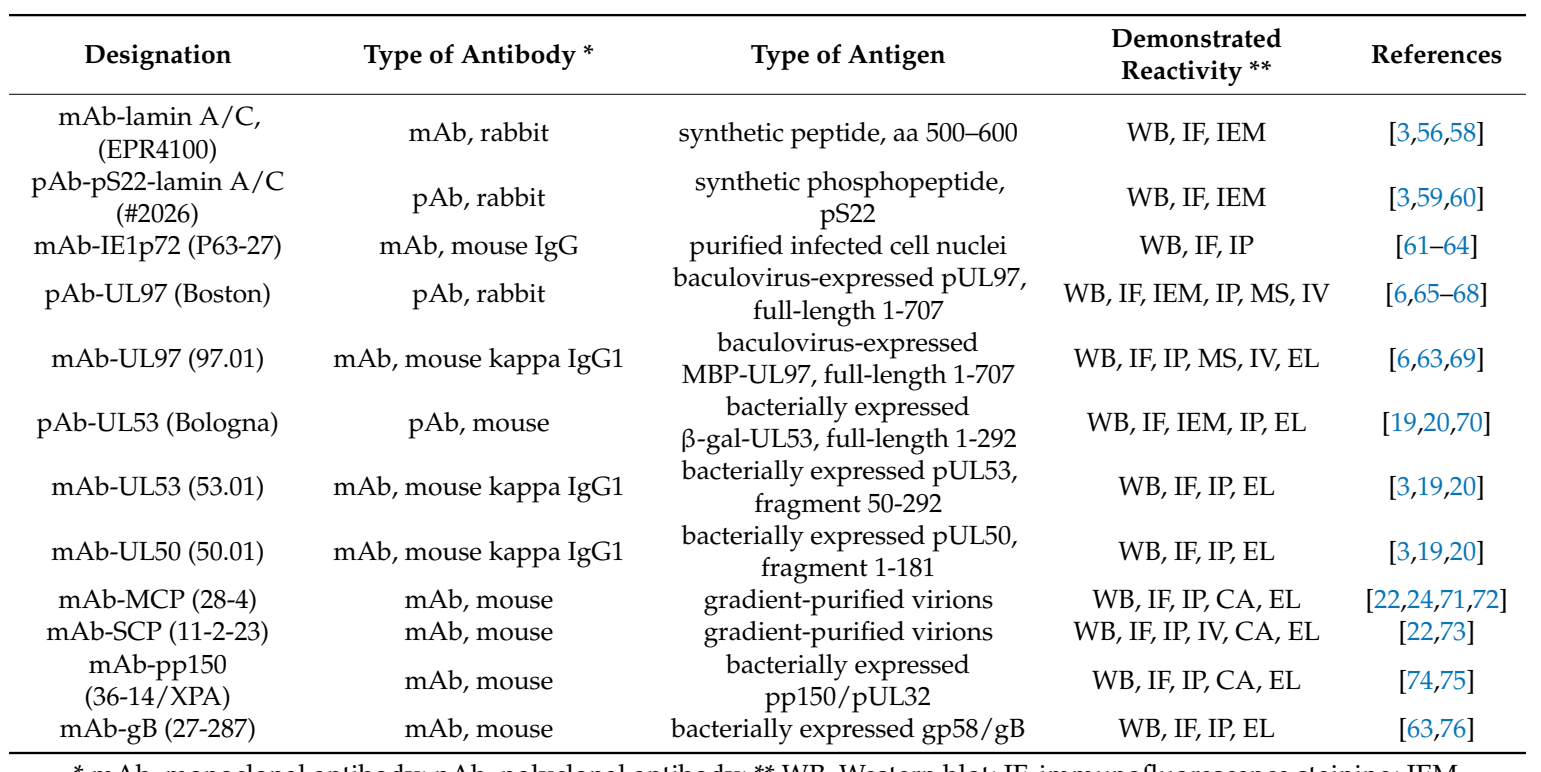

${ }^{*} \mathrm{mAb}$, monoclonal antibody; pAb, polyclonal antibody; ${ }^{* *} \mathrm{WB}$, Western blot; IF, immunofluorescence staining; IEM, immunogold labelling in electron microscopy; IP, immunoprecipitation; MS, mass spectrometry-based proteomics (IP with protein complexes); IV, IVKA (in vitro kinase assay/IP); CA, capsid-binding applications (IP with capsids); EL, ELISA (enzyme-linked immunosorbent assay).

\subsection{Co-immunoprecipitation (CoIP) Assay}

Two $175 \mathrm{~cm}^{2}$ cell culture flasks of HCMV-infected HFFs per sample were used for protein-protein interaction experiments utilizing CoIP. Immunoprecipitation from whole cell lysates (WCL) was performed three days post-infection (dpi) under previously described conditions using $2 \mu \mathrm{L}$ of mouse mAb-UL50 (50.01) or mAb-SCP (11-2-23). In addition, CoIP experiments were performed using cell-free virions (VIR) as input. To this end, viral particles from virus-containing supernatants of HFFs infected with HCMV strains AD169, TB40, Merlin, or Epstein-Barr virus (EBV) strain B95-8 were pelletized by a $3 \mathrm{~h}$ centrifugation step at $4{ }^{\circ} \mathrm{C}$ and $20,800 \mathrm{rcf}$. Subsequently, virus pellets were lysed in $500 \mu \mathrm{L}$ CoIP buffer (50 mM Tris/ $\mathrm{HCl}$ (pH 8.0), 150-300 mM NaCl, 5 mM EDTA, 0.5\% NP-40, 1 mM PMSF, $2 \mathrm{mg}$ aprotinin $\mathrm{mL}^{-1}, 2 \mathrm{mg}$ leupeptin $\mathrm{mL}^{-1}$ and $2 \mathrm{mg}$ pepstatin $\mathrm{mL}^{-1}$ ) and lysates were used for CoIP as described previously [77]. In every case, CoIP samples and expression controls taken prior to the addition of CoIP antibody (i.e. input) were subjected to standard Western blot analysis using mouse mAbs as follows: mAb-MCP (28-4), mAb-SCP (11-2-23), mAb-UL97 (97.01), mAb-UL50 (UL50.01) and mAb-UL53 (53.01) (produced by the authors of this study; see Table 2).

\subsection{In Vitro Kinase Assay (IVKA)}

Association of viral pUL97 kinase activity with nuclear HCMV capsids was determined in vitro after cell fractionation and immunoprecipitation of HCMV capsids. Therefore, the nuclear fraction of two $175 \mathrm{~cm}^{2}$ cell culture flasks of HCMV-infected HFFs per sample was isolated at 4 dpi using CST Cell Fractionation Kit \#9038 (Cell Signaling Technology) according to the manufacturer's protocol. 
HCMV capsids were immunoprecipitated from the isolated nuclear fraction with $2 \mu \mathrm{L}$ of mAb-SCP and subjected to IVKA reaction using $5 \mu \mathrm{Ci}$ of $\left[\gamma_{-}{ }^{33} \mathrm{P}\right]$ adenosine triphosphate (ATP) as described previously [77,78]. Finally, samples were prepared for separation by $12.5 \%$ SDS-PAGE, followed by transfer to nitrocellulose membrane (A. Hartenstein, Würzburg, Germany) for Western blotting. Autoradiographic membranes were exposed to a phosphorimager plate and measured using a CR 35 Bio phosphorimager (raytest Isotopenmessgeräte $\mathrm{GmbH}$, Straubenhardt, Germany).

\section{Results}

\subsection{Association of HCMV Capsids with the Core NEC Constituent pUL53 Visualized by Immuno-Gold Electron Microscopy}

The nuclear egress of HCMV capsids is regulated by the multifunctional NEC. However, the question as to how nuclear capsids are recruited to the NEC and to specific nuclear budding sites has not been answered yet. In order to address the intranuclear fine-localization of HCMV egress proteins, we performed immunostaining of viral proteins in ultrathin sections of infected-cell material evaluated by electron microscopy (immuno-EM). Primary human foreskin fibroblasts (HFFs) were infected with HCMV strain AD169 at a multiplicity of infection (MOI) of 2 and viral capsids were visualized at budding sites of the nuclear envelope at 3 days post-infection (dpi) (Figure 1a,b). Immuno-EM staining pointed to the association of viral pUL53, as a core NEC component, with nuclear capsids. The signal patterns strongly suggested a tight association of pUL53 with capsids currently budding at nuclear membranes (Figure 1a, filled arrowheads; $91 \%$ of analysed membrane-associated capsids were coated with gold particles) and even at times prior to reaching the nuclear envelope (Figure 1a,b, open arrowheads; $17 \%$ of intranuclear capsids were coated with gold particles). The specificity of the used primary and secondary antibodies has been proven in control stainings of mock-infected and HCMV-infected cells, respectively (Figure S1). This finding of pUL53-capsid interaction was reminiscent of a recent report on herpes simplex virus type 1 (HSV-1) capsid interaction with the pUL53 homolog pUL31, mainly based on fluorescence microscopic analyses [79].

In accordance with the EM data, the major capsid protein (MCP) was co-immunoprecipitated with the core NEC and the NEC-associated protein kinase pUL97 from HCMV-infected whole cell lysates (WCL) using a pUL50-specific antibody (i.e. mAb-UL50.01; Figure 1c). These findings were further supported by performing additional co-immunoprecipitation (CoIP) experiments. Using two different preparations of $\mathrm{mAb}-\mathrm{SCP}, \mathrm{MCP}$ was massively detected in the co-precipitate (Figure 2, middle panels). In addition, a minor quantity of pUL53 could also be detected (Figure 2a, upper panel). The low level of pUL53 found in the CoIP fraction with SCP might reflect the fact that only viral capsids budding at nuclear membranes showed a constant pUL53 association in the immunogold labelling electron microscopy (EM) analysis. It should, however, be noted as an important indication that pUL53 might be the first contact point for nuclear capsids when they approach the viral NEC.

\subsection{HCMV Kinase pUL97 Associates with Viral Capsids Already in the nucleus of Infected Cells}

The possibility that capsid association of pUL53 may also include pUL97 (Figure 1c), which is a multifunctional regulator that phosphorylates a number of substrates including pUL50 and pUL53 [20], prompted us to address further questions about the functional consequences of these protein interactions. To this end, we asked whether the protein kinase pUL97, particularly responsible for the major regulatory events in nuclear lamina rearrangement during viral egress, is likewise detectable by EM-based localization studies as a protein associated with nuclear capsids. In fact, a staining pattern of nuclear capsid co-localization was observed for pUL97 similar to pUL53 (although at some lower detectable quantity than pUL53, i.e., approx. 33\% of evaluated capsids were found pUL97-associated; Figure 3a). The signal distribution suggests an interaction of pUL97 with the surface interface of variable stages of nuclear particles (Figure $3 b, c)$. The specificity of the antibody staining 
was again analysed using mock-infected and HCMV-infected cells (Figure S2). Notably, the control images point to a specific detection of pUL97 in this EM analysis.

(a)

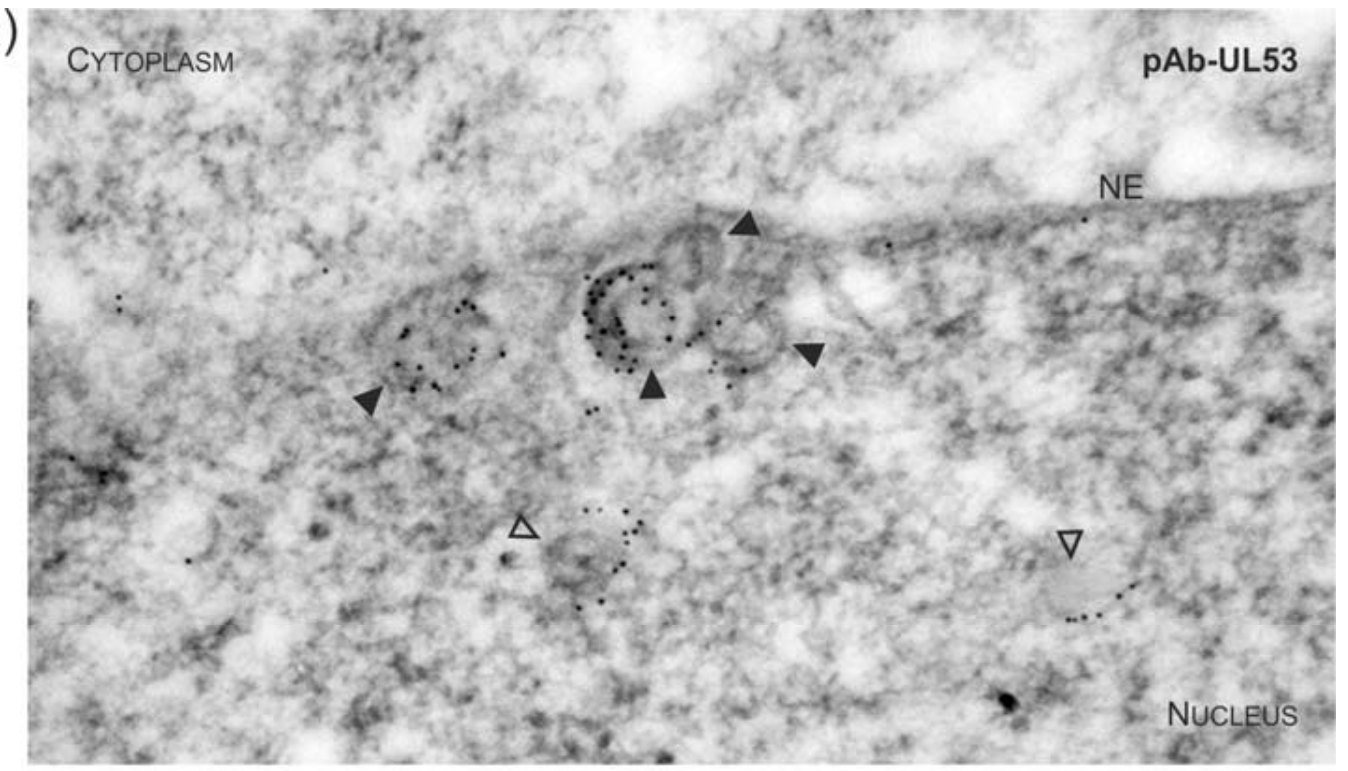

(b)

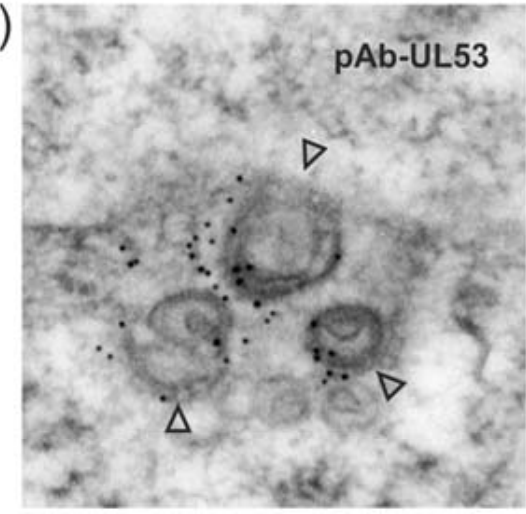

(c)

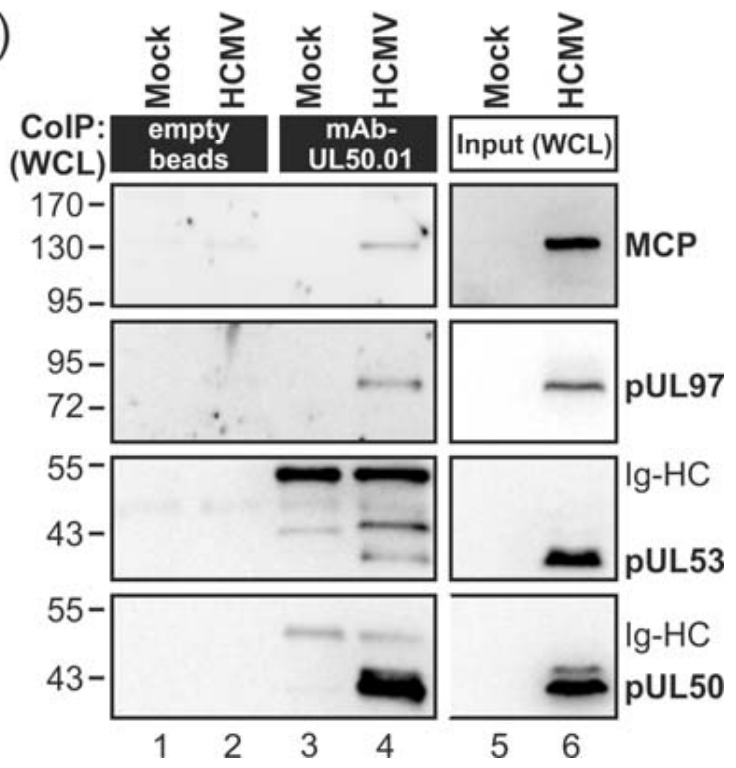

Figure 1. Association of the viral core nuclear egress complex (NEC) constituent pUL53 with intranuclear human cytomegalovirus (HCMV) capsids and capsids budding at the inner nuclear membrane (INM). (a,b) HCMV-infected primary human foreskin fibroblasts (HFFs) were harvested at $3 \mathrm{dpi}$ and subjected to immunogold staining of viral pUL53. Samples were analysed by transmission electron microscopy (TEM), 35,970-fold magnification. NE, nuclear envelope; open arrowheads, intranuclear HCMV capsids; filled arrowheads, HCMV capsids budding at nuclear membranes; (c) Co-immunoprecipitation (CoIP) analysis with HCMV-infected whole cell lysates (WCL). HCMVor uninfected (mock)-HFFs were lysed at $4 \mathrm{dpi}$ followed by immunoprecipitation with monoclonal antibody (mAb)-UL50.01 coupled to protein A sepharose (lanes 3-4) or empty beads as a CoIP negative control (lanes 1-2). CoIP samples (lanes 1-4) and expression control samples (input, representing one-twentieth of CoIP samples; lanes 5-6) were subjected to Western blot analysis using protein-specific antibodies. Ig-HC, cross-reactive band for immunoglobulin heavy chain; MCP, major capsid protein. 


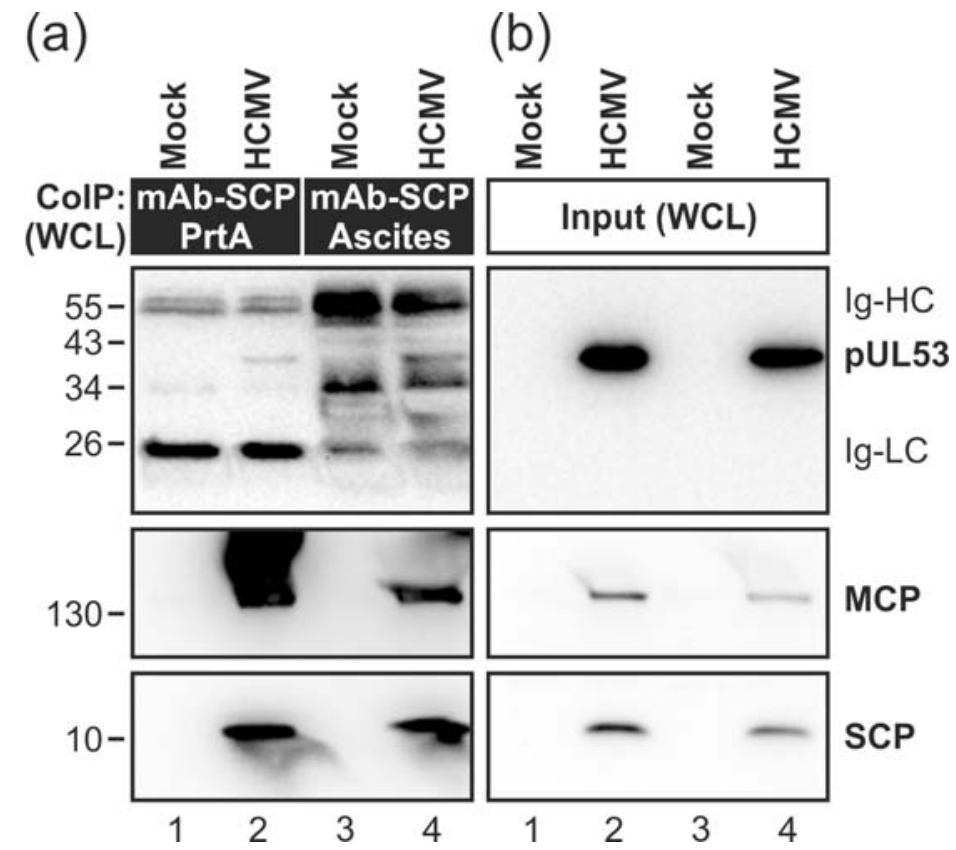

Figure 2. Interaction of HCMV capsid proteins SCP and MCP with the core NEC constituent pUL53. HFFs were infected with recombinant HCMV strain AD169 expressing the green fluorescent protein (GFP) or remained uninfected (mock) as indicated. Cells were lysed at $4 \mathrm{dpi}$ followed by immunoprecipitation with a monoclonal antibody $(\mathrm{mAb})$ against SCP produced as a protein A purified tissue culture supernatant (mAb-SCP PrtA; lanes 1-2) or ascites fluid (mAb-SCP Ascites; lanes 3-4). Co-immunoprecipitates (a) and expression control samples (input; (b)) were subjected to Western blot analysis using protein-specific antibodies. SCP, smallest capsid protein; $\mathrm{MCP}$, major capsid protein; Ig-HC and Ig-LC, cross-reactive band for immunoglobulin heavy and light chains.

Next, we confirmed the EM-based evidence of pUL97-capsid interaction by performing CoIP using protein lysates from virion stocks of the HCMV strains AD169, TB40 and Merlin. In this setting, mAb-SCP was able to co-immunoprecipitate both MCP and pUL97 (Figure 3d,e). For pUL97, the most prominent signals of interaction were obtained for strain AD169 (Figure 3e, lanes 1-2), which may relate to the high titre of this viral stock. It should be mentioned that SCP is highly conserved among the three strains, i.e., $>95 \%$ identity on amino acid level (with a single amino acid exchange of SCP Merlin at position V68I). Interestingly, SCP-detectable with a molecular weight of approx. $12 \mathrm{kDa}$ in control lysates (see Figure 2, lanes 2 and 4) -migrated at a high molecular size of $\geq 130 \mathrm{kDa}$, even larger than $\mathrm{MCP}$, in the input and immunoprecipitates from virion lysates (Figure 3d, lanes 1-2 and Figure 3e, lanes 1-3). One possible explanation would be a tightly linked packaging of SCP together with MCP in virions, which is not separable by standard denaturating SDS-PAGE. We confirmed the detectability of this high molecular form of SCP when we used whole cell lysates of HCMV-infected cells for CoIP with monoclonal antibodies against three different structural proteins, i.e., $\mathrm{mAb}-\mathrm{MCP}, \mathrm{mAb}-\mathrm{pp} 150$ and $\mathrm{mAb}-\mathrm{gB}$. Note that recent structural investigations proved the tight association of pp150 with capsids, particularly a pp150 cysteine tetrad-to-SCP interaction [23] (which might possibly not be completely resolved by SDS-PAGE). In our supplemental experiment, all three mAbs proved to be active in CoIP under these conditions and produced co-immunoprecipitates between MCP, pp150 and SCP (while gB appeared to be mostly separated by the use of detergents in the CoIP lysis buffer). Specifically, for SCP two forms were detected, namely the small 12-kDa SCP and an inseparable high molecular weight form $\geq 130 \mathrm{kDa}$, which might represent a covalent conjugate either with pp150 or a so far undefined other protein (Figure S3). 
(a)

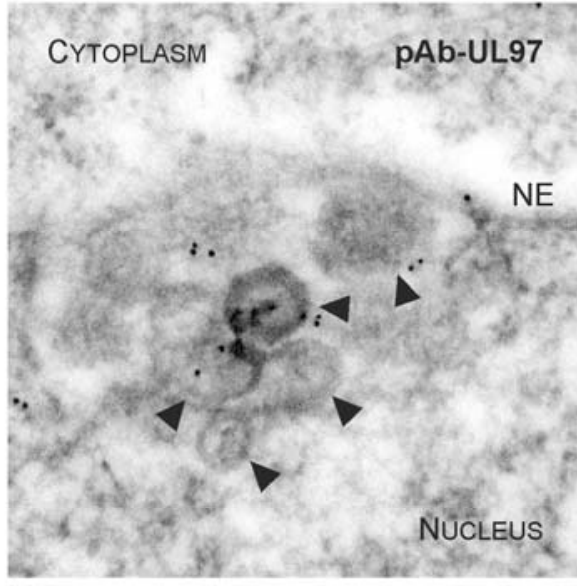

(e)

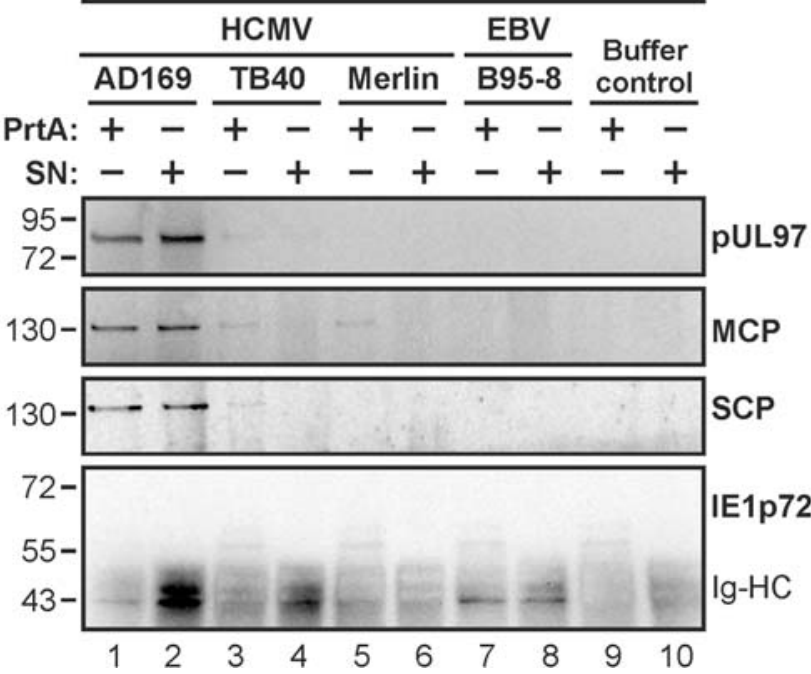

(b)

(c)
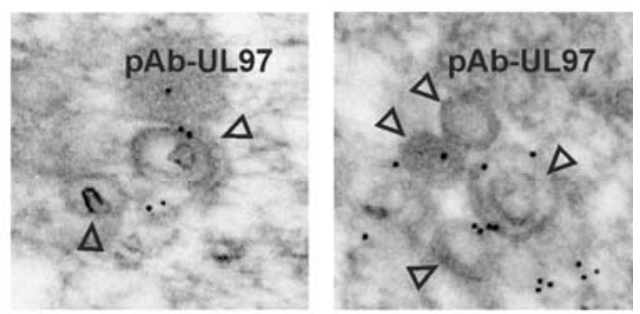

(d)
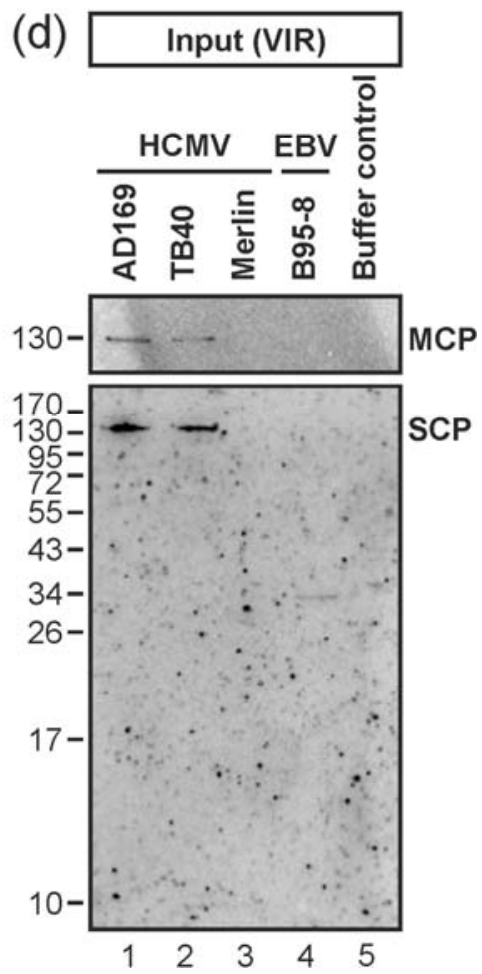

Figure 3. Association of the HCMV-encoded protein kinase pUL97 with viral capsids in the nucleus. (a-c) HCMV-infected HFFs were harvested at 3 dpi and subjected to immunogold staining of viral pUL97. Samples were analysed by TEM, 35,970-fold magnification. NE, nuclear envelope; open arrowheads, intranuclear HCMV capsids; filled arrowheads, HCMV capsids budding at nuclear membranes; $(\mathbf{d}, \mathbf{e})$ CoIP analysis with cell-free virions (VIR) as input. Virions from HCMV strains AD169, TB40 or Merlin (harvested from identical quantities of HFF producer cell layers, i.e., one T175 flask each) were lysed followed by CoIP using protein A-purified mAb-SCP (PrtA) or unpurified supernatant of $\mathrm{mAb}-\mathrm{SCP}$ hybridoma cultures (SN). EBV strain B95-8 or buffer served as CoIP negative controls ((d) lanes 4-5; (e) lanes 7-10). CoIP samples (e) and expression control samples (input; (d)) were both subjected to Western blot analysis using antibodies against the indicated proteins. Note, no band was detected at the molecular weight of approximately $72 \mathrm{kDa}$ using an antibody directed against immediate early protein 1 (IE1p72; (e), lower panel) pointing to the specificity of the CoIP. Ig-HC, cross-reactive band for immunoglobulin heavy chain.

In order to substantiate the potential interaction between pUL97 and HCMV capsids, we investigated if nucleocapsid-associated pUL97 exerts kinase activity. For this purpose, nuclear extracts were prepared from HCMV-infected fibroblasts and pUL97 was co-immunoprecipitated with nuclear HCMV capsids by the use of mAb-SCP. An assessment of pUL97 autophosphorylation activity was performed by in vitro kinase assays (IVKA). The results indicated capsid-associated activity of pUL97 (Figure 4a, lane 1; see pUL97 autophosphorylation, lower panel). The three previously characterized isoforms of pUL97, all known to possess autophosphorylation activity [67], were labelled to illustrate 
the specificity of the bands. The autoradiography shows a reduction of pUL97 autophosphorylation activity (Figure 4a, lane 1, lower panel) by pUL97 inhibitor MBV (Figure 4a, lane 2, lower panel).

(a)

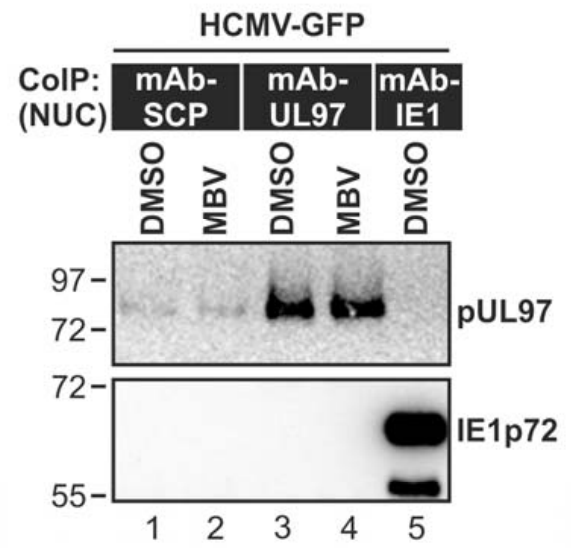

(b)

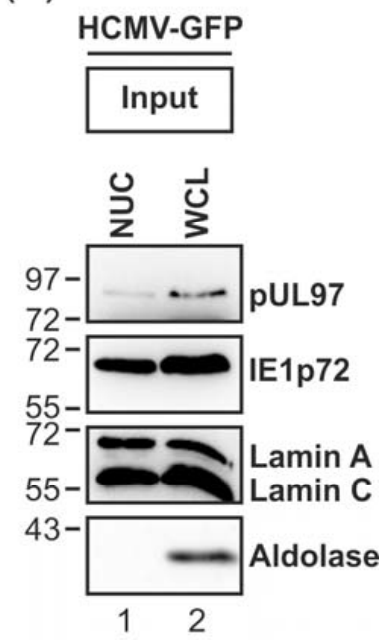

pUL97

Autoradiography: autophos.

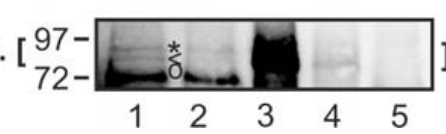

isoforms $\mathrm{M} 1 *, \mathrm{M} 74<, \mathrm{M} 1570$

Figure 4. The kinase activity of capsid-associated pUL97 purified from the nucleus of HCMV-infected cells. HFFs were infected with recombinant HCMV AD169-GFP and treated with the pUL97 kinase inhibitor maribavir (MBV) or the solvent dimethylsulfoxide (DMSO). At 4 dpi, cells were harvested and the nuclear fraction (NUC) was isolated from whole cell lysates (WCL). The nuclear fraction was used for immunoprecipitation of HCMV-encoded proteins SCP, pUL97, or IE1p72 as a control. Precipitates were subjected subsequently to a pUL97-specific in vitro kinase assay (IVKA). ((a), upper panels CoIP) Prior to IVKA reactions, the quality of CoIP samples was verified by Western blot analysis. ((a), lower panel Autoradiography) IVKA reactions were performed under conditions optimized for pUL97 activity and signals of autophosphorylation are depicted. Note the labelling of the three known isoforms of pUL97, M1, M74 and M157, which all possess autophosphorylation activity; (b) The input levels of all relevant proteins were stained on parallel Western blot panels.

Maximal activity of pUL97 was monitored by the use of mAb-UL97 (Figure 4a, lanes 3-4) and the specificity of the reaction was controlled by mAb-IE1, not showing any background signal of pUL97 activity (Figure 4a, lane 5; for expression levels of viral proteins and the success of nuclear extraction, i.e., separation of nuclear lamins A/C from cytoplasmic aldolase, are shown in Figure 4b). This result argues for very early binding of catalytically active pUL97 to nuclear stages of viral capsids that may be required for subsequent steps of nuclear egress regulation. Note that this IVKA result may provide a first argument for pUL97-capsid interaction, either through direct or indirect contact possibly involving further NEC proteins.

\subsection{Targeted Mode of Lamina Disassembly by Capsid-Associated pUL97}

To visualize virus-induced phosphorylation of the nuclear lamina, which is mainly mediated by pUL97 kinase activity [4,18,52,56,80,81], monoclonal or polycolonal antibodies $(\mathrm{mAb} / \mathrm{pAb})$ against nuclear lamin $\mathrm{A} / \mathrm{C}$ were used for immuno-EM, either recognizing lamins in a phosphorylation-independent or phosphorylation-dependent manner (Figure 5, Figure 6 and Figure S4). As previous reports demonstrated a major site of lamin phosphorylation at position serine 22, pAb-pS22-lamin A/C was applied in this analysis (Figure $6 \mathrm{c}-\mathrm{e}$ ) and was compared to signals obtained for overall lamin A/C detection with mAb-lamin A/C (Figures 5 and $6 a, b)$. The homogeneous rim-like distribution of lamin A/C signals observed in uninfected cells (Mock, Figure 5a and Figure S4b) was 
drastically altered in HCMV-infected cells; i.e., a thinning of lamin A/C-specific immuno-EM grains was detected (Figure $5 b$ and Figure S4a), which corresponds to the earlier description of nuclear lamina thinning and the induction of LDAs [52,54]. The typical pattern of lamin redistribution in HCMV-infected cells includes lamina thinning and the formation of lamina-depleted areas. However, it was surprising to detect that despite of the low concentration of lamina-associated gold particles at the nuclear envelope of HCMV-infected cells, budding events were exclusively found at sites which were still decorated with lamin A/C , (Figures $5 \mathrm{~b}$ and $6 \mathrm{a}$, filled arrowheads). In fact, staining with pAb-pS22-lamin A/C suggested that this portion of lamin A/C is still phosphorylated at serine 22 (Figure $6 \mathrm{c}$ and Figure $\mathrm{S4e}$ ) which is a prerequisite for lamin dissociation from the nuclear envelope. Interestingly, a similar association of lamins, stained with either mAb-lamin A/C or the phospho-specific pAb-pS22-lamin A/C, was observed with capsids adjacent to intranuclear membranes (Figure 6b,d). These structures resemble previously described large tubular INM infoldings which were postulated to be utilized for nuclear egress of human and mouse cytomegalovirus (MCMV) capsids [53]. Taken together, it is intriguing to speculate that nuclear capsids not only interact with the viral core NEC and pUL97 but also with nuclear lamins, which undergo site-specific phosphorylation during the process of nuclear egress in a capsid/NEC-associated manner.

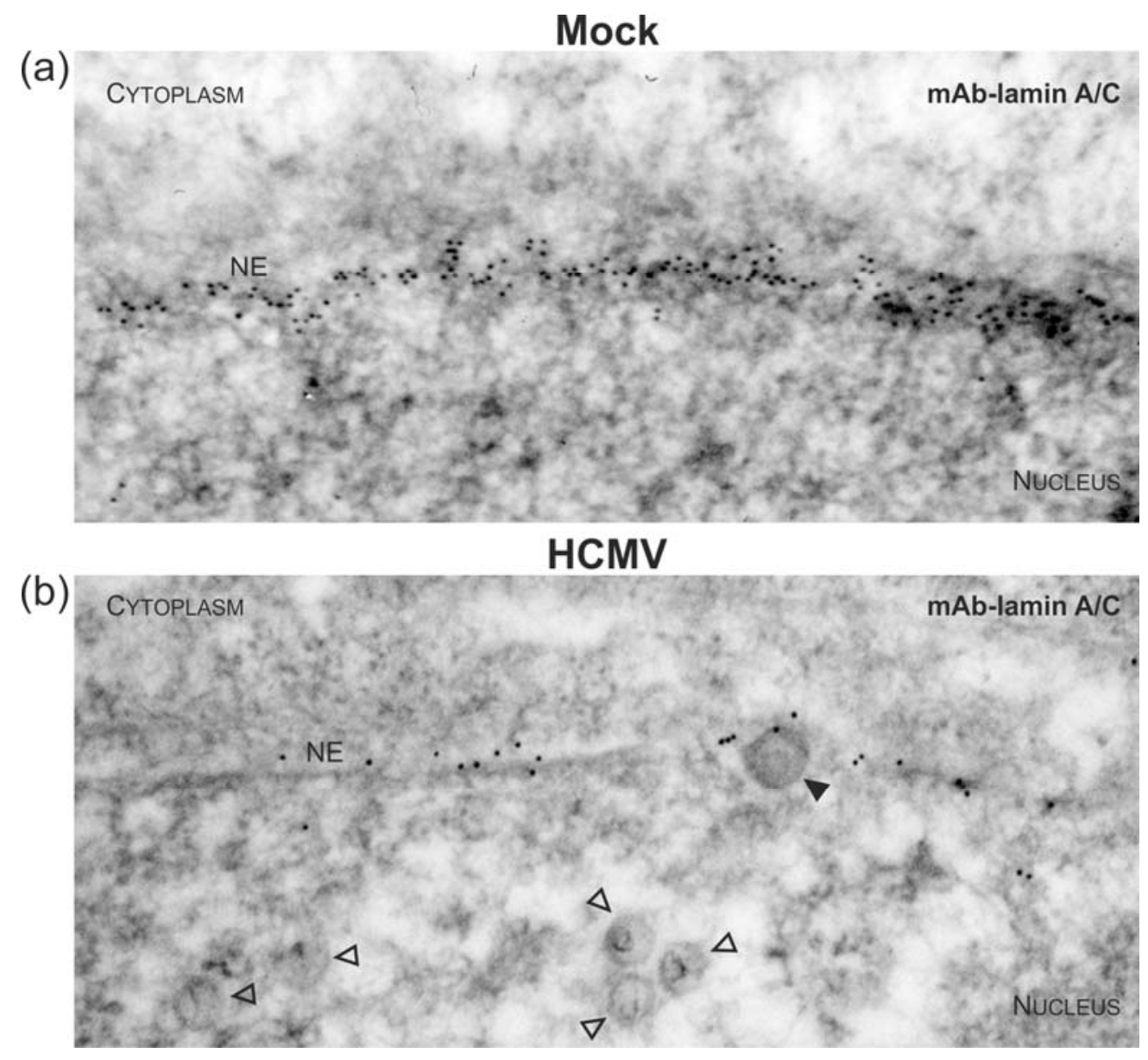

Figure 5. Disassembly of the nuclear lamina during nuclear egress of HCMV capsids visualized by electron microscopy. HFFs were infected with HCMV strain AD169 (b) or remained uninfected (mock; (a)) as indicated. Cells were harvested at 3 dpi and subjected to immunogold staining of A-type lamins (i.e. lamin A/C). Samples were analysed by TEM, 35,970-fold magnification. NE, nuclear envelope; open arrowheads, intranuclear HCMV capsids; filled arrowheads, HCMV capsids budding at nuclear membranes. 
(a)

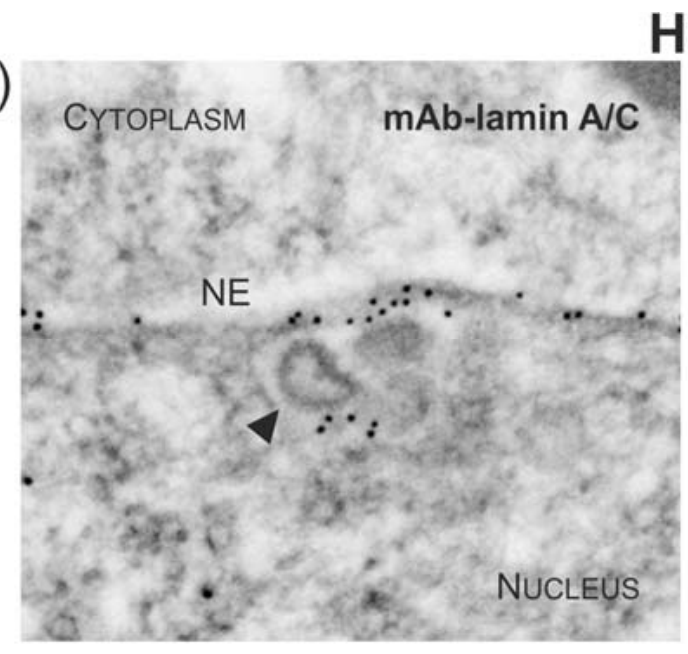

(c)

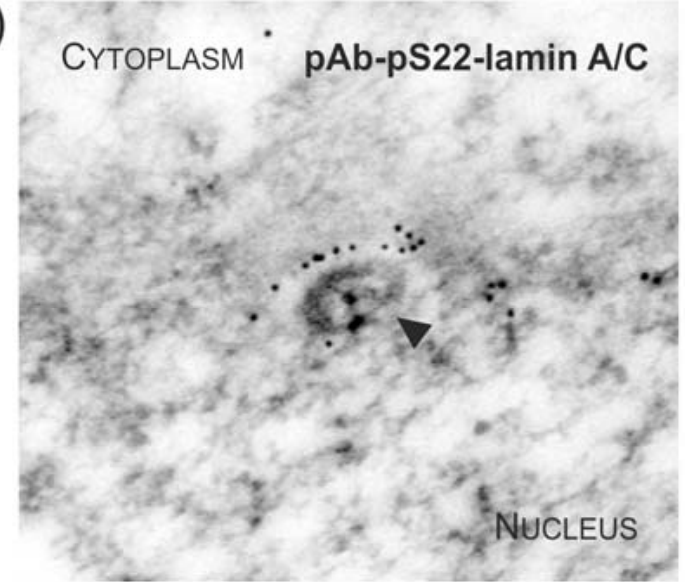

\section{HCMV}

(b)

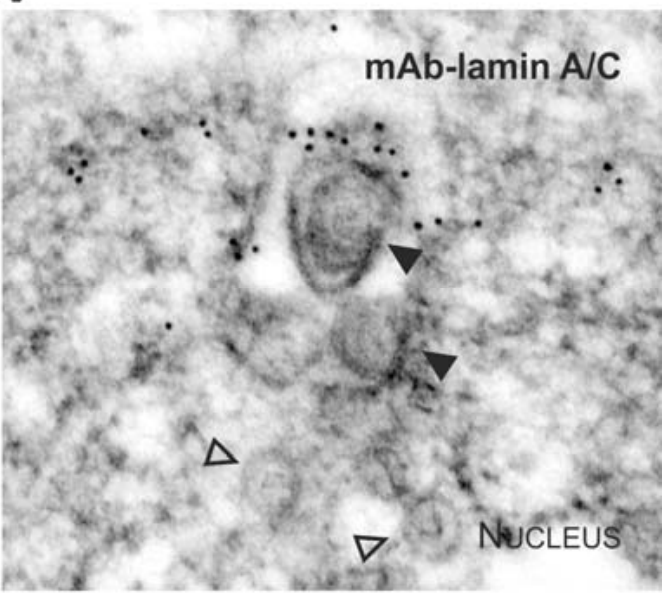

(d)

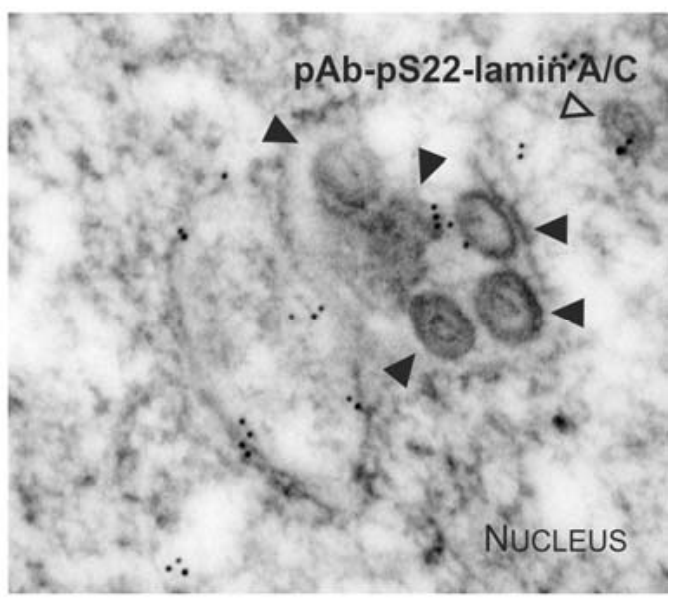

\section{Mock}

(e)

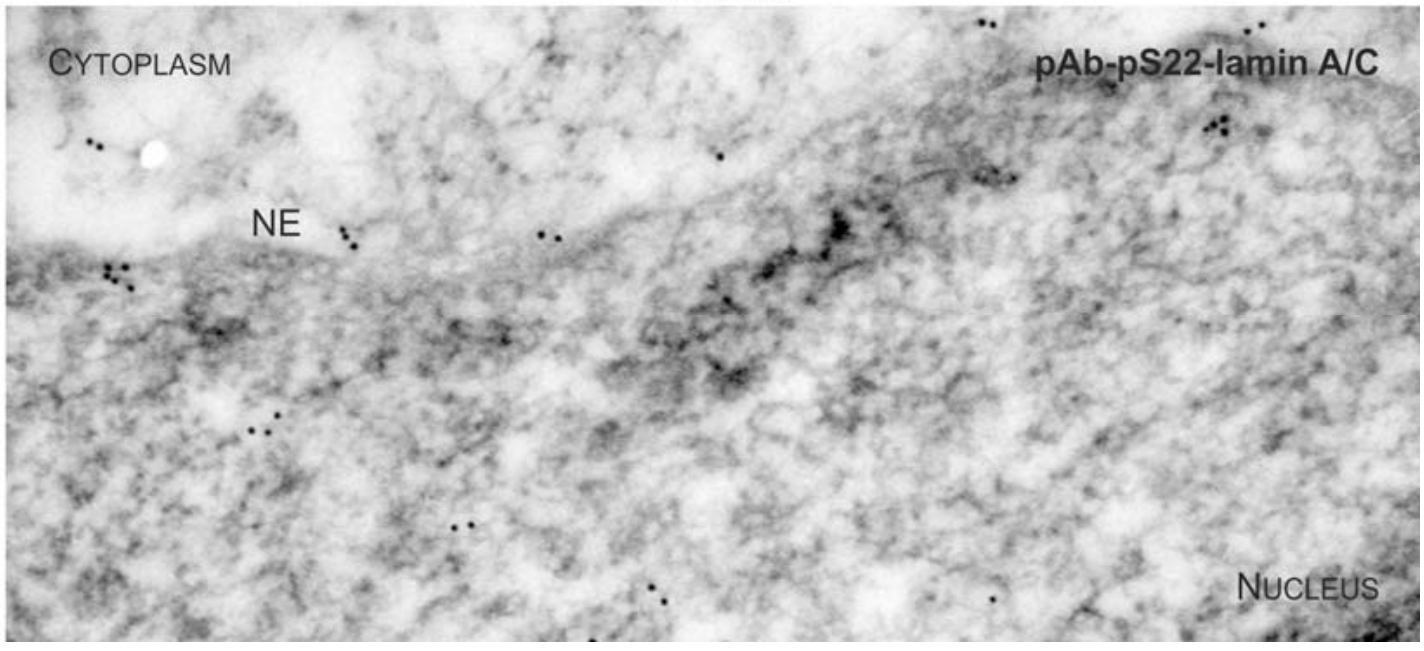

Figure 6. Accumulation of phosphorylated nuclear lamins at INM-budding sites of HCMV capsids during nuclear egress. HCMV-infected (a-d) or uninfected (mock; (e)) HFFs were stained with phosphorylation-independent $(\mathbf{a}, \mathbf{b})$ or phosphorylation-dependent (c-e) lamin A/C primary antibodies and gold-tagged secondary antibodies. Samples were analysed by TEM, 35,970-fold magnification. NE, nuclear envelope; open arrowheads, intranuclear HCMV capsids; filled arrowheads, HCMV capsids budding at nuclear membranes. 


\section{Discussion}

A series of recent reports addressed questions about the regulation of HCMV nuclear egress orchestrated by the HCMV-specific core NEC forming a multi-component viral-cellular NEC extension reviewed by [15]. However, the association of the NEC with HCMV nuclear capsids remained enigmatic in several aspects. Our study focused on experimental approaches illustrating the association of viral capsids with the HCMV-specific core NEC and viral protein kinase pUL97 (Figure 7). The central findings were as follows: (i) nuclear HCMV capsids may directly associate with NEC proteins at viral budding sites of the nuclear lamina; (ii) the core NEC constituent pUL53 and viral protein kinase pUL97 showed, at least to some extent, intranuclear interaction with virions; (iii) in vitro kinase assays provided initial evidence for kinase activity of capsid-associated pUL97; and (iv) immune-EM staining patterns using phospho-specific and phospho-independent lamin A/C antibodies are compatible with our earlier postulate of a targeted mode of virion egress at lamina-depleted areas.

Data presented in this study on the association of pUL53 with intranuclear HCMV capsids appear to be congruent with previous reports using HSV-1 and pseudorabies virus (PRV), in which it was demonstrated that the core NEC of these two alpha-herpesviruses binds to viral capsids [82-84]. In particular, the PRV and HSV-1 pUL31 proteins, homologs of HCMV pUL53, were identified to be enriched on purified viral particles and pUL31-capsid binding was shown to be independent of its core NEC partner pUL34 [82,83]. Consistent with this, we observed HCMV pUL53 associated with viral capsids in the nucleus of infected cells by EM immunogold staining. Interestingly, this was not restricted to capsids located at the nuclear envelope, presumably budding into the perinuclear space but pUL53 coating was also observed on capsids which had not yet reached the INM. Co-immunoprecipitation analyses confirmed that pUL53, as well as its core NEC partner pUL50, is strongly suggested to be bound to the structural capsid proteins MCP and SCP. In a previous study, we identified MCP and the HCMV triplex protein pUL85 associated with pUL50-pUL53 when analysing complexes from HCMV-infected cells by mass spectrometry [3]. As all these proteins, $\mathrm{MCP}$, SCP and pUL85, represent structural components, they may provide a direct link between nuclear viral particles and the core NEC. In previous studies, we and others showed that pUL50 is targeted to the INM, probably exclusively due to the function of its transmembrane domain [78,85-87]. The immunogold-EM data presented in this study suggests that capsid binding may be mediated by the pUL53 component of the core NEC. In line with this, based on the crystal structures of the core NECs of HCMV, HSV-1 and PrV [88-91], a conserved alpha-helix in pUL53 at the membrane-distal end of the NEC was proposed to mediate binding to the capsid [11,14].

To this end, it remains to be elucidated whether an additional viral or cellular capsid-associated protein may support this interaction. Notably, candidate proteins for the recognition of capsids by the core NEC were recently proposed for HSV-1 [83,84]. The HSV-1 homolog of pUL53 binds to a complex of the HSV-1-encoded proteins pUL17 and pUL25 [83]. These proteins, together with a third HSV-1 protein, i.e., pUL36, belong to a heterotrimeric complex located exclusively at the vertices of the icosahedral herpesviral capsid, which is therefore termed capsid vertex-specific complex (CVSC) [25]. Due to preferential loading of the CVSC on DNA-containing capsids (termed C capsids), binding of the core NEC to the CVSC might provide the mechanistic basis of a quality control to assure nuclear egress of only mature C capsids. The general importance of the CVSC for HSV-1 nuclear egress was at least shown for pUL25 [92]. In the absence of pUL25, neither primary enveloped particles in the perinuclear space nor capsids in the cytoplasm were observed by transmission electron microscopy (TEM), although all capsid types, including $C$ capsids, were regularly formed and even were detected frequently adjacent to the INM [92]. In the case of HCMV, there is conflicting evidence as to whether the homologous CVSC proteins, pUL77 and pUL93, can interact with one of the core NEC proteins $[93,94]$. 

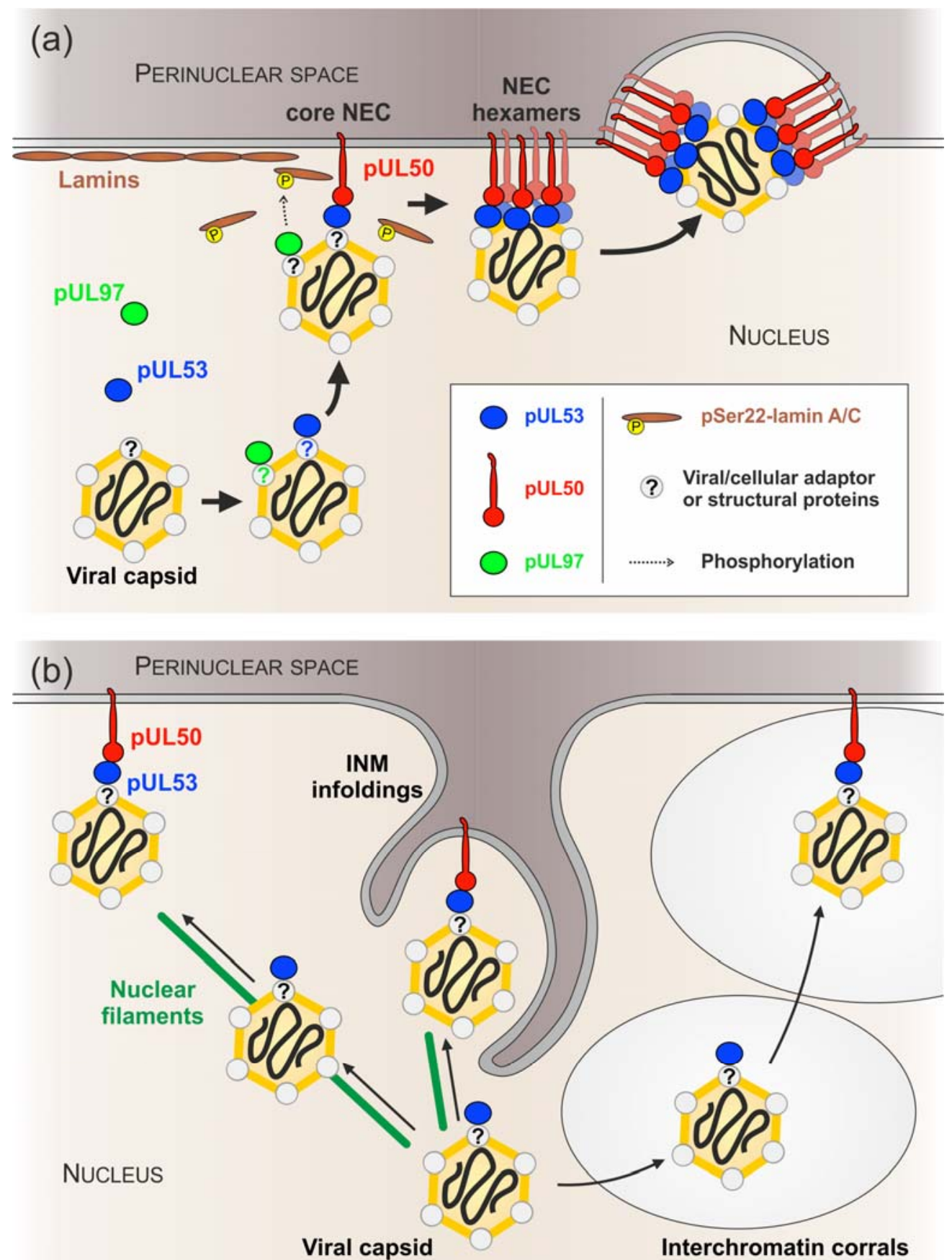

Figure 7. Schematic presentation of theoretical options that may lead to the recruitment of HCMV capsids to INM budding sites. (a) First, core NEC component pUL53 and NEC-associated protein kinase pUL97 bind to viral capsids in the nucleoplasm. Binding might be mediated directly via structural viral proteins (e.g., MCP, SCP, pUL85, or CVSC proteins) or indirectly via viral or cellular adaptor proteins. Second, pUL53-coated capsids dock to membrane-anchored pUL50 under formation of the core NEC. Capsid-associated pUL97 might be responsible for phosphorylation of remaining lamin A/C molecules providing access to the INM. Hexameric core NEC assemblies finally initiate budding into the perinuclear space; (b) Depiction of putative mechanisms of how HCMV capsids reach the INM are depicted on the basis of evidence mainly provided by this study and studies with alpha-herpesviruses. Black solid arrows define optional directions of capsid transport/trafficking. See description of individual possibilities in the main text. Diagrams not to scale. 
The presented data furthermore suggests that at least a portion of pUL53, which is not yet incorporated into the NEC located at the INM, associates with HCMV capsids somewhere in the nucleoplasm. It is tempting to speculate that pUL53-coated capsids might subsequently reach the INM to dock to membrane-bound pUL50. This is consistent with the recently revealed mechanism of capsid transport to the INM based on free diffusion through chromatin-devoid areas (i.e. interchromatin corrals) enlarged in herpesvirus-infected cells (Figure 7b) [95,96]. It is worthy of note that final capsid docking at the INM might require hexameric assemblies of the core NEC as postulated recently [15]. In particular, according to the recent crystal structures, the HCMV core NEC forms hexameric ring-like arrangements [88]. The stoichiometry and size of these rings matches that of the hexon-ordered arrangements of the major capsid protein. For this reason, it seems plausible that both hexameric structures, i.e., NEC and capsids, may directly interact with each other during nuclear egress [15]. However, such an interaction would also imply that the monomeric building blocks of these structures, e.g., pUL53 and an individual capsid protein, may additionally be capable to interact with each other, although with much lower affinity.

This point was strongly illustrated by our theoretical estimate, which generally suggests an increase of affinity resulting from multivalent interactions compared to monomeric interactions. We speculated whether monomeric pUL53 interaction with capsids might occur at a lower affinity than multivalent interaction of the hexameric pUL50-pUL53 NEC with capsids. For this purpose, an inspection of the literature was compiled in Table 3 references [97-107]. Most of the examples refer to protein-ligand interactions that gain affinity upon multimerization. For example, the Sos1 protein contains five proline-rich motifs that interact with the two SH3 domains of Grb2. The effective dissociation constant $\left(\mathrm{K}_{\mathrm{d}}\right)$ for the formation of a Sos1-Grb2 complex is 100 times smaller than the smallest $\mathrm{K}_{\mathrm{d}}$ for the binding of a single Grb2 SH3 domain to a proline-rich motif on Sos1 [99]. In addition, there are also several examples demonstrating that this principle similarly applies to the interaction of proteins with lipids, sugars, or DNA (Table 3). For example, the multimeric protein $\mathrm{S}$ binds with at least 250-fold higher affinity to phospholipid bilayers compared to monomeric protein S [97]. For the methyl-CpG-binding domain (MBD) protein, which recognizes methylated CpG sites in double-stranded DNA, a covalently linked tetramer binds DNA more than 50 fold tighter than a monomeric MBD [98]. The gain in affinity for the multimeric interactions ranges from one to five orders of magnitude depending on the nature and stoichiometry of the interaction. The highest gain in affinity ( $>10^{4}$ fold) is observed for a pentameric compared to a monomeric ligand binding to the pentameric heat-labile enterotoxin (Table 3). From all systems referenced, the stoichiometry is closest to that of a putative hexamer-hexamer interaction between HCMV core NEC and capsid. Thus, we propose that a hexameric compared to a monomeric kind of NEC-capsid interaction would cause a rather large gain in affinity that might even exceed the values reported in Table 3.

Moreover, immunogold-EM confirmed previous studies based on confocal microscopy, which stated that local disassembly of the nuclear lamina was induced in HCMV-infected cells $[4,18,52,80]$. However, it was surprising to see that the remaining lamin A/C was enriched at capsid budding sites of the nuclear envelope. The use of a phospho-dependent antibody indicated that these lamin A/C molecules are already phosphorylated at serine 22 and, therefore, are likely to be dissociated from the residual nuclear lamina $[56,108]$. Consistent with this, we hypothesized that the HCMV protein kinase pUL97 may also bind to capsids in the nucleus (Figure 7a). It is known that pUL97, being a component of the herpesvirus-characteristic tegument layer, is packaged into HCMV particles, which are released from the host cell $[109,110]$. However, to date, it is not clear whether a substantial quantity of pUL97 already associates with HCMV capsids in the nucleus or in a later step during maturation in the cytoplasm. Thus, it remains to be elucidated whether pUL97 is permanently associated with capsids during nuclear egress and cytoplasmic maturation or whether nuclear capsid-binding of pUL97 is transient and final tegumentation of pUL97 takes place at a later stage in the cytoplasm. 
Table 3. Published examples of increased affinities resulting from multivalent types of protein-ligand interaction.

\begin{tabular}{|c|c|c|c|c|}
\hline First Binding Partner & Second Binding Partner & Type of Complex Formed & Gain in Affinity & References \\
\hline $\mathrm{S}$ protein & Phospholipid bilayer & Multimeric protein S & $>250$ fold & [97] \\
\hline MBD protein & DNA CpG sites & Tetrameric MBD & $>50$ fold & [98] \\
\hline Grb SH3 domain & Proline-rich motif of SOS & $\begin{array}{l}\text { Two SH3 domains and five } \\
\text { proline-rich motifs }\end{array}$ & $>100$ fold & [99] \\
\hline ZAP70 SH2 domain & ITAM motifs of Syk kinase & $\begin{array}{l}\text { Two SH2 domains and two } \\
\text { ITAM motifs }\end{array}$ & $>100$ fold & [100] \\
\hline HPV E6 protein & Peptidic ligand & Bivalent peptidic ligand & $>300$ fold & [101] \\
\hline Lectins & Sugar ligands & Multimeric lectins and ligands & $\begin{array}{l}1-3 \text { orders of } \\
\text { magnitude }\end{array}$ & [102] \\
\hline $\begin{array}{l}\text { Staphylococcal } \\
\text { protein A }\end{array}$ & Affibody & Dimeric affibody & $\begin{array}{l}3 \text { orders of } \\
\text { magnitude }\end{array}$ & [103] \\
\hline Monoclonal IgG I & $\begin{array}{l}\text { Fc } \gamma \text { receptors RIIA } \\
\text { and RIIIB }\end{array}$ & Dimeric IgG I & 200-800 fold & [104] \\
\hline $\begin{array}{l}\text { Receptor tyrosine } \\
\text { kinase VEGFR-2 }\end{array}$ & Peptidic ligand & Dimeric peptidic ligand & 6-500 fold & [105] \\
\hline $\begin{array}{c}\text { E. coli heat-labile } \\
\text { enterotoxin (pentamer) }\end{array}$ & Galactose (monomer) & $\begin{array}{l}\text { Five galactose moieties linked } \\
\text { by a pentavalent scaffold }\end{array}$ & $>10^{4}$ fold & {$[106,107]$} \\
\hline
\end{tabular}

\section{Conclusions}

In conclusion, we provide novel insights into the specific mechanisms and protein interactions relevant to HCMV nuclear egress. In particular, data are consistent with the idea that the core NEC constituent pUL53 may be involved in the transport of newly assembled HCMV capsids from the nucleoplasm to the nuclear envelope (Figure 7a). It remains to be determined whether this process really involves an active recruitment of capsids along nuclear filaments such as F-actin that, in addition, may essentially be dependent on pUL53. Alternatively, it seems suggestive that nuclear envelope targeting of capsids may be mediated by crossing interchromatin corrals by Brownian motion in the end connected with the capsids' pUL53-pUL50 core NEC interaction. In both cases, current data suggests that budding into the perinuclear space can either occur at the nuclear envelope or even at large INM infoldings (Figure $7 \mathrm{~b}$ ). Future studies will have to provide more molecular data to confirm this concept and to clarify further details of the process.

Supplementary Materials: Supplementary materials can be found at www.mdpi.com/1999-4915/10/1/35/s1.

Acknowledgments: The authors are grateful to Eva-Maria Borst (Virology, MHH, Hannover, Germany), Elke Bogner (Virology, Charité, Berlin, Germany) and Thomas Stamminger and co-workers (Virology, FAU Erlangen-Nürnberg, Germany) for their cooperation in antibody/virus production, electron microscopy experiments and the sharing of an inventory of HCMV reagents and techniques. We also wish to thank Patrick König for processing electron microscopy images, Martin Schütz for very helpful laboratory research assistance and Victoria Jackiw for support with manuscript editing (Language Centre, FAU Erlangen-Nürnberg). This work was supported by Deutsche Forschungsgemeinschaft (grants SFB796/C3, MA1289/8-1 and MI2143/2-1).

Author Contributions: Jens Milbradt and Manfred Marschall conceived and designed the experiments; Jens Milbradt, Eric Sonntag, Sabrina Wagner, Hanife Strojan, Christina Wangen and Ursula Schlötzer-Schrehardt performed the experiments; Jens Milbradt, Heinrich Sticht, Ursula Schlötzer-Schrehardt and Manfred Marschall analysed the data; Tihana Lenac Rovis, Berislav Lisnic, Stipan Jonjic and William J. Britt contributed reagents and materials; Jens Milbradt, Heinrich Sticht, Ursula Schlötzer-Schrehardt and Manfred Marschall wrote the paper.

Conflicts of Interest: The authors declare no conflict of interest.

\section{References}

1. Mocarski, E.S.; Shenk, T.; Griffiths, P.D.; Pass, R.F. Cytomegaloviruses. In Fields Virology, 6th ed.; Knipe, D.M., Howley, P.M., Eds.; Wolters Kluwer Lippincott Williams \& Wilkins: Philadelphia, PA, USA, 2013; pp. 1960-2014.

2. Griffiths, P.; Baraniak, I.; Reeves, M. The pathogenesis of human cytomegalovirus. J. Pathol. 2015, 235, 288-297. [CrossRef] [PubMed] 
3. Milbradt, J.; Kraut, A.; Hutterer, C.; Sonntag, E.; Schmeiser, C.; Ferro, M.; Wagner, S.; Lenac, T.; Claus, C.; Pinkert, S.; et al. Proteomic analysis of the multimeric nuclear egress complex of human cytomegalovirus. Mol. Cell. Proteom. 2014, 13, 2132-2146. [CrossRef] [PubMed]

4. Sharma, M.; Coen, D.M. Comparison of effects of inhibitors of viral and cellular protein kinases on human cytomegalovirus disruption of nuclear lamina and nuclear egress. J. Virol. 2014, 88, 10982-10985. [CrossRef] [PubMed]

5. Lemnitzer, F.; Raschbichler, V.; Kolodziejczak, D.; Israel, L.; Imhof, A.; Bailer, S.M.; Koszinowski, U.; Ruzsics, Z. Mouse cytomegalovirus egress protein pM50 interacts with cellular endophilin-a2. Cell. Microbiol. 2013, 15, 335-351. [CrossRef] [PubMed]

6. Steingruber, M.; Kraut, A.; Socher, E.; Sticht, H.; Reichel, A.; Stamminger, T.; Amin, B.; Coute, Y.; Hutterer, C.; Marschall, M. Proteomic interaction patterns between human cyclins, the cyclin-dependent kinase ortholog pUL97 and additional cytomegalovirus proteins. Viruses 2016, 8. [CrossRef] [PubMed]

7. Hagen, C.; Dent, K.C.; Zeev-Ben-Mordehai, T.; Grange, M.; Bosse, J.B.; Whittle, C.; Klupp, B.G.; Siebert, C.A.; Vasishtan, D.; Bauerlein, F.J.; et al. Structural basis of vesicle formation at the inner nuclear membrane. Cell 2015, 163, 1692-1701. [CrossRef] [PubMed]

8. Hennig, T.; O’Hare, P. Viruses and the nuclear envelope. Curr. Opin. Cell Biol. 2015, 34, 113-121. [CrossRef] [PubMed]

9. Johnson, D.C.; Baines, J.D. Herpesviruses remodel host membranes for virus egress. Nat. Rev. Microbiol. 2011, 9, 382-394. [CrossRef] [PubMed]

10. Lee, C.P.; Chen, M.R. Escape of herpesviruses from the nucleus. Rev. Med. Virol. 2010, 20, 214-230. [CrossRef] [PubMed]

11. Mettenleiter, T.C. Vesicular nucleo-cytoplasmic transport-herpesviruses as pioneers in cell biology. Viruses 2016, 8, 266. [CrossRef] [PubMed]

12. Lye, M.F.; Wilkie, A.R.; Filman, D.J.; Hogle, J.M.; Coen, D.M. Getting to and through the inner nuclear membrane during herpesvirus nuclear egress. Curr. Opin. Cell Biol. 2017, 46, 9-16. [CrossRef] [PubMed]

13. Hellberg, T.; Passvogel, L.; Schulz, K.S.; Klupp, B.G.; Mettenleiter, T.C. Nuclear egress of herpesviruses: The prototypic vesicular nucleocytoplasmic transport. Adv. Virus Res. 2016, 94, 81-140. [PubMed]

14. Bigalke, J.M.; Heldwein, E.E. Nuclear exodus: Herpesviruses lead the way. Annu. Rev. Virol. 2016, 3, $387-409$. [CrossRef] [PubMed]

15. Marschall, M.; Muller, Y.A.; Diewald, B.; Sticht, H.; Milbradt, J. The human cytomegalovirus nuclear egress complex unites multiple functions: Recruitment of effectors, nuclear envelope rearrangement, and docking to nuclear capsids. Rev. Med. Virol. 2017, 27. [CrossRef] [PubMed]

16. Bigalke, J.M.; Heuser, T.; Nicastro, D.; Heldwein, E.E. Membrane deformation and scission by the hsv-1 nuclear egress complex. Nat. Commun. 2014, 5, 4131. [CrossRef] [PubMed]

17. Bigalke, J.M.; Heldwein, E.E. Have nec coat, will travel: Structural basis of membrane budding during nuclear egress in herpesviruses. Adv. Virus Res. 2017, 97, 107-141. [PubMed]

18. Marschall, M.; Marzi, A.; aus dem Siepen, P.; Jochmann, R.; Kalmer, M.; Auerochs, S.; Lischka, P.; Leis, M.; Stamminger, T. Cellular p32 recruits cytomegalovirus kinase pul97 to redistribute the nuclear lamina. J. Biol. Chem. 2005, 280, 33357-33367. [CrossRef] [PubMed]

19. Sonntag, E.; Hamilton, S.T.; Bahsi, H.; Wagner, S.; Jonjic, S.; Rawlinson, W.D.; Marschall, M.; Milbradt, J. Cytomegalovirus pUL50 is the multi-interacting determinant of the core nuclear egress complex (NEC) that recruits cellular accessory nec components. J. Gen. Virol. 2016, 97, 1676-1685. [PubMed]

20. Sonntag, E.; Milbradt, J.; Svrlanska, A.; Strojan, H.; Hage, S.; Kraut, A.; Hesse, A.M.; Amin, B.; Sonnewald, U.; Coute, Y.; et al. Protein kinases responsible for the phosphorylation of the nuclear egress core complex of human cytomegalovirus. J. Gen. Virol. 2017, 98, 2569-2581. [CrossRef] [PubMed]

21. Bowman, B.R.; Baker, M.L.; Rixon, F.J.; Chiu, W.; Quiocho, F.A. Structure of the herpesvirus major capsid protein. EMBO J. 2003, 22, 757-765. [CrossRef] [PubMed]

22. Dai, X.; Yu, X.; Gong, H.; Jiang, X.; Abenes, G.; Liu, H.; Shivakoti, S.; Britt, W.J.; Zhu, H.; Liu, F.; et al. The smallest capsid protein mediates binding of the essential tegument protein pp150 to stabilize DNA-containing capsids in human cytomegalovirus. PLoS Pathog. 2013, 9, 15. [CrossRef] [PubMed]

23. Yu, X.; Jih, J.; Jiang, J.; Zhou, Z.H. Atomic structure of the human cytomegalovirus capsid with its securing tegument layer of pp150. Science 2017, 356. [CrossRef] [PubMed] 
24. Lai, L.; Britt, W.J. The interaction between the major capsid protein and the smallest capsid protein of human cytomegalovirus is dependent on two linear sequences in the smallest capsid protein. J. Virol. 2003, 77, 2730-2735. [CrossRef] [PubMed]

25. Heming, J.D.; Conway, J.F.; Homa, F.L. Herpesvirus capsid assembly and DNA packaging. Adv. Anat. Embryol. Cell Biol. 2017, 223, 119-142. [PubMed]

26. Cardone, G.; Winkler, D.C.; Trus, B.L.; Cheng, N.; Heuser, J.E.; Newcomb, W.W.; Brown, J.C.; Steven, A.C. Visualization of the herpes simplex virus portal in situ by cryo-electron tomography. Virology 2007, 361, 426-434. [CrossRef] [PubMed]

27. Chang, J.T.; Schmid, M.F.; Rixon, F.J.; Chiu, W. Electron cryotomography reveals the portal in the herpesvirus capsid. J. Virol. 2007, 81, 2065-2068. [CrossRef] [PubMed]

28. Newcomb, W.W.; Juhas, R.M.; Thomsen, D.R.; Homa, F.L.; Burch, A.D.; Weller, S.K.; Brown, J.C. The UL6 gene product forms the portal for entry of DNA into the herpes simplex virus capsid. J. Virol. 2001, 75, 10923-10932. [CrossRef] [PubMed]

29. Trus, B.L.; Cheng, N.; Newcomb, W.W.; Homa, F.L.; Brown, J.C.; Steven, A.C. Structure and polymorphism of the UL6 portal protein of herpes simplex virus type 1. J. Virol. 2004, 78, 12668-12671. [CrossRef] [PubMed]

30. Abbotts, A.P.; Preston, V.G.; Hughes, M.; Patel, A.H.; Stow, N.D. Interaction of the herpes simplex virus type 1 packaging protein UL15 with full-length and deleted forms of the UL28 protein. J. Gen. Virol. 2000, 81, 2999-3009. [CrossRef] [PubMed]

31. Beard, P.M.; Taus, N.S.; Baines, J.D. DNA cleavage and packaging proteins encoded by genes U(L)28, U(L)15, and $\mathrm{U}(\mathrm{L}) 33$ of herpes simplex virus type 1 form a complex in infected cells. J. Virol. 2002, 76, 4785-4791. [CrossRef] [PubMed]

32. Higgs, M.R.; Preston, V.G.; Stow, N.D. The UL15 protein of herpes simplex virus type 1 is necessary for the localization of the UL28 and UL33 proteins to viral DNA replication centres. J. Gen. Virol. 2008, 89, 1709-1715. [CrossRef] [PubMed]

33. Koslowski, K.M.; Shaver, P.R.; Casey, J.T., 2nd; Wilson, T.; Yamanaka, G.; Sheaffer, A.K.; Tenney, D.J.; Pederson, N.E. Physical and functional interactions between the herpes simplex virus UL15 and UL28 DNA cleavage and packaging proteins. J. Virol. 1999, 73, 1704-1707. [PubMed]

34. Reynolds, A.E.; Fan, Y.; Baines, J.D. Characterization of the U(L)33 gene product of herpes simplex virus 1. Virology 2000, 266, 310-318. [CrossRef] [PubMed]

35. White, C.A.; Stow, N.D.; Patel, A.H.; Hughes, M.; Preston, V.G. Herpes simplex virus type 1 portal protein UL6 interacts with the putative terminase subunits UL15 and UL28. J. Virol. 2003, 77, 6351-6358. [CrossRef] [PubMed]

36. Fan, W.H.; Roberts, A.P.; McElwee, M.; Bhella, D.; Rixon, F.J.; Lauder, R. The large tegument protein pUL36 is essential for formation of the capsid vertex-specific component at the capsid-tegument interface of herpes simplex virus 1. J. Virol. 2015, 89, 1502-1511. [CrossRef] [PubMed]

37. Huet, A.; Makhov, A.M.; Huffman, J.B.; Vos, M.; Homa, F.L.; Conway, J.F. Extensive subunit contacts underpin herpesvirus capsid stability and interior-to-exterior allostery. Nat. Struct. Mol. Biol. 2016, 23, 531-539. [CrossRef] [PubMed]

38. Tandon, R.; Mocarski, E.S. Viral and host control of cytomegalovirus maturation. Trends Microbiol. 2012, 20, 392-401. [CrossRef] [PubMed]

39. Loveland, A.N.; Nguyen, N.L.; Brignole, E.J.; Gibson, W. The amino-conserved domain of human cytomegalovirus UL80a proteins is required for key interactions during early stages of capsid formation and virus production. J. Virol. 2007, 81, 620-628. [CrossRef] [PubMed]

40. Oien, N.L.; Thomsen, D.R.; Wathen, M.W.; Newcomb, W.W.; Brown, J.C.; Homa, F.L. Assembly of herpes simplex virus capsids using the human cytomegalovirus scaffold protein: Critical role of the c terminus. J. Virol. 1997, 71, 1281-1291. [PubMed]

41. Nguyen, N.L.; Loveland, A.N.; Gibson, W. Nuclear localization sequences in cytomegalovirus capsid assembly proteins (UL80 proteins) are required for virus production: Inactivating nls1, nls2, or both affects replication to strikingly different extents. J. Virol. 2008, 82, 5381-5389. [CrossRef] [PubMed]

42. Wood, L.J.; Baxter, M.K.; Plafker, S.M.; Gibson, W. Human cytomegalovirus capsid assembly protein precursor (pUL80.5) interacts with itself and with the major capsid protein (pUL86) through two different domains. J. Virol. 1997, 71, 179-190. [PubMed] 
43. Neuber, S.; Wagner, K.; Goldner, T.; Lischka, P.; Steinbrueck, L.; Messerle, M.; Borst, E.M. Mutual interplay between the human cytomegalovirus terminase subunits pUL51, pUL56, and pUL89 promotes terminase complex formation. J. Virol. 2017, 91, e02384-16. [CrossRef] [PubMed]

44. Borst, E.M.; Wagner, K.; Binz, A.; Sodeik, B.; Messerle, M. The essential human cytomegalovirus gene UL52 is required for cleavage-packaging of the viral genome. J. Virol. 2008, 82, 2065-2078. [CrossRef] [PubMed]

45. Koppen-Rung, P.; Dittmer, A.; Bogner, E. Intracellular distribution of capsid-associated pUL77 of human cytomegalovirus and interactions with packaging proteins and pUL93. J. Virol. 2016, 90, 5876-5885. [CrossRef] [PubMed]

46. Meissner, C.S.; Koppen-Rung, P.; Dittmer, A.; Lapp, S.; Bogner, E. A “coiled-coil” motif is important for oligomerization and DNA binding properties of human cytomegalovirus protein UL77. PLoS ONE 2011, 6, e25115. [CrossRef] [PubMed]

47. Holzenburg, A.; Dittmer, A.; Bogner, E. Assembly of monomeric human cytomegalovirus pul104 into portal structures. J. Gen. Virol. 2009, 90, 2381-2385. [CrossRef] [PubMed]

48. Johannsen, E.; Luftig, M.; Chase, M.R.; Weicksel, S.; Cahir-McFarland, E.; Illanes, D.; Sarracino, D.; Kieff, E. Proteins of purified epstein-barr virus. Proc. Natl. Acad. Sci. USA 2004, 101, 16286-16291. [CrossRef] [PubMed]

49. Chiu, S.H.; Wu, M.C.; Wu, C.C.; Chen, Y.C.; Lin, S.F.; Hsu, J.T.; Yang, C.S.; Tsai, C.H.; Takada, K.; Chen, M.R.; et al. Epstein-barr virus BALF3 has nuclease activity and mediates mature virion production during the lytic cycle. J. Virol. 2014, 88, 4962-4975. [CrossRef] [PubMed]

50. Pavlova, S.; Feederle, R.; Gartner, K.; Fuchs, W.; Granzow, H.; Delecluse, H.J. An epstein-barr virus mutant produces immunogenic defective particles devoid of viral DNA. J. Virol. 2013, 87, 2011-2022. [CrossRef] [PubMed]

51. Lee, C.P.; Liu, P.T.; Kung, H.N.; Su, M.T.; Chua, H.H.; Chang, Y.H.; Chang, C.W.; Tsai, C.H.; Liu, F.T.; Chen, M.R. The escrt machinery is recruited by the viral bfrf1 protein to the nucleus-associated membrane for the maturation of epstein-barr virus. PLoS Pathog. 2012, 8, e1002904. [CrossRef] [PubMed]

52. Milbradt, J.; Webel, R.; Auerochs, S.; Sticht, H.; Marschall, M. Novel mode of phosphorylation-triggered reorganization of the nuclear lamina during nuclear egress of human cytomegalovirus. J. Biol. Chem. 2010, 285, 13979-13989. [CrossRef] [PubMed]

53. Buser, C.; Walther, P.; Mertens, T.; Michel, D. Cytomegalovirus primary envelopment occurs at large infoldings of the inner nuclear membrane. J. Virol. 2007, 81, 3042-3048. [CrossRef] [PubMed]

54. Villinger, C.; Neusser, G.; Kranz, C.; Walther, P.; Mertens, T. 3D analysis of homv induced-nuclear membrane structures by fib/sem tomography: Insight into an unprecedented membrane morphology. Viruses 2015, 7, 5686-5704. [CrossRef] [PubMed]

55. Marschall, M.; Feichtinger, S.; Milbradt, J. Regulatory roles of protein kinases in cytomegalovirus replication. Adv. Virus Res. 2011, 80, 69-101. [PubMed]

56. Milbradt, J.; Hutterer, C.; Bahsi, H.; Wagner, S.; Sonntag, E.; Horn, A.H.; Kaufer, B.B.; Mori, Y.; Sticht, H.; Fossen, T.; et al. The prolyl isomerase Pin1 promotes the herpesvirus-induced phosphorylation-dependent disassembly of the nuclear lamina required for nucleocytoplasmic egress. PLoS Pathog. 2016, 12. [CrossRef] [PubMed]

57. Marschall, M.; Freitag, M.; Weiler, S.; Sorg, G.; Stamminger, T. Recombinant green fluorescent protein-expressing human cytomegalovirus as a tool for screening antiviral agents. Antimicrob. Agents Chemother. 2000, 44, 1588-1597. [CrossRef] [PubMed]

58. Ranade, D.; Koul, S.; Thompson, J.; Prasad, K.B.; Sengupta, K. Chromosomal aneuploidies induced upon lamin B2 depletion are mislocalized in the interphase nucleus. Chromosoma 2017, 126, 223-244. [CrossRef] [PubMed]

59. Mullers, E.; Silva Cascales, H.; Burdova, K.; Macurek, L.; Lindqvist, A. Residual CDK1/2 activity after DNA damage promotes senescence. Aging Cell 2017, 16, 575-584. [CrossRef] [PubMed]

60. Sun, X.; Bristol, J.A.; Iwahori, S.; Hagemeier, S.R.; Meng, Q.; Barlow, E.A.; Fingeroth, J.D.; Tarakanova, V.L.; Kalejta, R.F.; Kenney, S.C. Hsp90 inhibitor 17-dmag decreases expression of conserved herpesvirus protein kinases and reduces virus production in epstein-barr virus-infected cells. J. Virol. 2013, 87, 10126-10138. [CrossRef] [PubMed] 
61. Andreoni, M.; Faircloth, M.; Vugler, L.; Britt, W.J. A rapid microneutralization assay for the measurement of neutralizing antibody reactive with human cytomegalovirus. J. Virol. Methods 1989, 23, 157-167. [CrossRef]

62. Plachter, B.; Britt, W.; Vornhagen, R.; Stamminger, T.; Jahn, G. Analysis of proteins encoded by ie regions 1 and 2 of human cytomegalovirus using monoclonal antibodies generated against recombinant antigens. Virology 1993, 193, 642-652. [CrossRef] [PubMed]

63. Hutterer, C.; Wandinger, S.K.; Wagner, S.; Muller, R.; Stamminger, T.; Zeittrager, I.; Godl, K.; Baumgartner, R.; Strobl, S.; Marschall, M. Profiling of the kinome of cytomegalovirus-infected cells reveals the functional importance of host kinases Aurora A, Abl and Ampk. Antivir. Res. 2013, 99, 139-148. [CrossRef] [PubMed]

64. Hutterer, C.; Hamilton, S.; Steingruber, M.; Zeittrager, I.; Bahsi, H.; Thuma, N.; Naing, Z.; Orfi, Z.; Orfi, L.; Socher, E.; et al. The chemical class of quinazoline compounds provides a core structure for the design of anticytomegaloviral kinase inhibitors. Antivir. Res. 2016, 134, 130-143. [CrossRef] [PubMed]

65. Kamil, J.P.; Coen, D.M. Human cytomegalovirus protein kinase UL97 forms a complex with the tegument phosphoprotein pp65. J. Virol. 2007, 81, 10659-10668. [CrossRef] [PubMed]

66. Baek, M.C.; Krosky, P.M.; Coen, D.M. Relationship between autophosphorylation and phosphorylation of exogenous substrates by the human cytomegalovirus UL97 protein kinase. J. Virol. 2002, 76, 11943-11952. [CrossRef] [PubMed]

67. Webel, R.; Hakki, M.; Prichard, M.N.; Rawlinson, W.D.; Marschall, M.; Chou, S. Differential properties of cytomegalovirus pUL97 kinase isoforms affect viral replication and maribavir susceptibility. J. Virol. 2014, 88, 4776-4785. [CrossRef] [PubMed]

68. He, Z.; He, Y.S.; Kim, Y.; Chu, L.; Ohmstede, C.; Biron, K.K.; Coen, D.M. The human cytomegalovirus UL97 protein is a protein kinase that autophosphorylates on serines and threonines. J. Virol. 1997, 71, 405-411. [PubMed]

69. Steingruber, M.; Socher, E.; Hutterer, C.; Webel, R.; Bergbrede, T.; Lenac, T.; Sticht, H.; Marschall, M. The interaction between cyclin b1 and cytomegalovirus protein kinase pUL97 is determined by an active kinase domain. Viruses 2015, 7, 4582-4601. [CrossRef] [PubMed]

70. Dal Monte, P.; Pignatelli, S.; Zini, N.; Maraldi, N.M.; Perret, E.; Prevost, M.C.; Landini, M.P. Analysis of intracellular and intraviral localization of the human cytomegalovirus UL53 protein. J. Gen. Virol. 2002, 83, 1005-1012. [CrossRef] [PubMed]

71. Rechter, S.; Konig, T.; Auerochs, S.; Thulke, S.; Walter, H.; Dornenburg, H.; Walter, C.; Marschall, M. Antiviral activity of arthrospira-derived spirulan-like substances. Antivir. Res. 2006, 72, 197-206. [CrossRef] [PubMed]

72. Konig, P.; Buscher, N.; Steingruber, M.; Socher, E.; Sticht, H.; Tenzer, S.; Plachter, B.; Marschall, M. Dynamic regulatory interaction between cytomegalovirus major tegument protein pp65 and protein kinase pUL97 in intracellular compartments, dense bodies and virions. J. Gen. Virol. 2017. [CrossRef] [PubMed]

73. Gibson, W.; Clopper, K.S.; Britt, W.J.; Baxter, M.K. Human cytomegalovirus (hcmv) smallest capsid protein identified as product of short open reading frame located between hcmv UL48 and UL49. J. Virol. 1996, 70, 5680-5683. [PubMed]

74. Sanchez, V.; Greis, K.D.; Sztul, E.; Britt, W.J. Accumulation of virion tegument and envelope proteins in a stable cytoplasmic compartment during human cytomegalovirus replication: Characterization of a potential site of virus assembly. J. Virol. 2000, 74, 975-986. [CrossRef] [PubMed]

75. Greis, K.D.; Gibson, W.; Hart, G.W. Site-specific glycosylation of the human cytomegalovirus tegument basic phosphoprotein (UL32) at serine 921 and serine 952. J. Virol. 1994, 68, 8339-8349. [PubMed]

76. Utz, U.; Britt, W.; Vugler, L.; Mach, M. Identification of a neutralizing epitope on glycoprotein gp58 of human cytomegalovirus. J. Virol. 1989, 63, 1995-2001. [PubMed]

77. Milbradt, J.; Auerochs, S.; Sticht, H.; Marschall, M. Cytomegaloviral proteins that associate with the nuclear lamina: Components of a postulated nuclear egress complex. J. Gen. Virol. 2009, 90, 579-590. [CrossRef] [PubMed]

78. Milbradt, J.; Auerochs, S.; Marschall, M. Cytomegaloviral proteins pUL50 and pUL53 are associated with the nuclear lamina and interact with cellular protein kinase c. J. Gen. Virol. 2007, 88, 2642-2650. [CrossRef] [PubMed]

79. Funk, C.; Ott, M.; Raschbichler, V.; Nagel, C.H.; Binz, A.; Sodeik, B.; Bauerfeind, R.; Bailer, S.M. The herpes simplex virus protein pUL31 escorts nucleocapsids to sites of nuclear egress, a process coordinated by its n-terminal domain. PLoS Pathog. 2015, 11, e1004957. [CrossRef] [PubMed] 
80. Hamirally, S.; Kamil, J.P.; Ndassa-Colday, Y.M.; Lin, A.J.; Jahng, W.J.; Baek, M.C.; Noton, S.; Silva, L.A.; Simpson-Holley, M.; Knipe, D.M.; et al. Viral mimicry of cdc2/cyclin-dependent kinase 1 mediates disruption of nuclear lamina during human cytomegalovirus nuclear egress. PLoS Pathog. 2009, 5, 23. [CrossRef] [PubMed]

81. Kuny, C.V.; Chinchilla, K.; Culbertson, M.R.; Kalejta, R.F. Cyclin-dependent kinase-like function is shared by the beta- and gamma-subset of the conserved herpesvirus protein kinases. PLoS Pathog. 2010, 6, 1001092. [CrossRef] [PubMed]

82. Leelawong, M.; Guo, D.; Smith, G.A. A physical link between the pseudorabies virus capsid and the nuclear egress complex. J. Virol. 2011, 85, 11675-11684. [CrossRef] [PubMed]

83. Yang, K.; Baines, J.D. Selection of hsv capsids for envelopment involves interaction between capsid surface components pUL31, pUL17, and pUL25. Proc. Natl. Acad. Sci. USA 2011, 108, 14276-14281. [CrossRef] [PubMed]

84. Yang, K.; Wills, E.; Lim, H.Y.; Zhou, Z.H.; Baines, J.D. Association of herpes simplex virus pUL31 with capsid vertices and components of the capsid vertex-specific complex. J. Virol. 2014, 88, 3815-3825. [CrossRef] [PubMed]

85. Sam, M.D.; Evans, B.T.; Coen, D.M.; Hogle, J.M. Biochemical, biophysical, and mutational analyses of subunit interactions of the human cytomegalovirus nuclear egress complex. J. Virol. 2009, 83, 2996-3006. [CrossRef] [PubMed]

86. Schmeiser, C.; Borst, E.; Sticht, H.; Marschall, M.; Milbradt, J. The cytomegalovirus egress proteins pUL50 and pUL53 are translocated to the nuclear envelope through two distinct modes of nuclear import. J. Gen. Virol. 2013, 94, 2056-2069. [CrossRef] [PubMed]

87. Sharma, M.; Kamil, J.P.; Coughlin, M.; Reim, N.I.; Coen, D.M. Human cytomegalovirus UL50 and UL53 recruit viral protein kinase UL97, not protein kinase c, for disruption of nuclear lamina and nuclear egress in infected cells. J. Virol. 2014, 88, 249-262. [CrossRef] [PubMed]

88. Walzer, S.A.; Egerer-Sieber, C.; Sticht, H.; Sevvana, M.; Hohl, K.; Milbradt, J.; Muller, Y.A.; Marschall, M. Crystal structure of the human cytomegalovirus pUL50-pUL53 core nuclear egress complex provides insight into a unique assembly scaffold for virus-host protein interactions. J. Biol. Chem. 2015, 290, 27452-27458. [CrossRef] [PubMed]

89. Lye, M.F.; Sharma, M.; El Omari, K.; Filman, D.J.; Schuermann, J.P.; Hogle, J.M.; Coen, D.M. Unexpected features and mechanism of heterodimer formation of a herpesvirus nuclear egress complex. EMBO J. 2015, 34, 2937-2952. [CrossRef] [PubMed]

90. Bigalke, J.M.; Heldwein, E.E. Structural basis of membrane budding by the nuclear egress complex of herpesviruses. EMBO J. 2015, 34, 2921-2936. [CrossRef] [PubMed]

91. Zeev-Ben-Mordehai, T.; Weberruss, M.; Lorenz, M.; Cheleski, J.; Hellberg, T.; Whittle, C.; El Omari, K.; Vasishtan, D.; Dent, K.C.; Harlos, K.; et al. Crystal structure of the herpesvirus nuclear egress complex provides insights into inner nuclear membrane remodeling. Cell. Rep. 2015, 13, 2645-2652. [CrossRef] [PubMed]

92. Klupp, B.G.; Granzow, H.; Keil, G.M.; Mettenleiter, T.C. The capsid-associated UL25 protein of the alphaherpesvirus pseudorabies virus is nonessential for cleavage and encapsidation of genomic DNA but is required for nuclear egress of capsids. J. Virol. 2016, 80, 6235-6246. [CrossRef] [PubMed]

93. Borst, E.M.; Bauerfeind, R.; Binz, A.; Stephan, T.M.; Neuber, S.; Wagner, K.; Steinbruck, L.; Sodeik, B.; Lenac Rovis, T.; Jonjic, S.; et al. The essential human cytomegalovirus proteins pUL77 and pUL93 are structural components necessary for viral genome encapsidation. J. Virol. 2016, 90, 5860-5875. [CrossRef] [PubMed]

94. DeRussy, B.M.; Boland, M.T.; Tandon, R. Human cytomegalovirus pUL93 links nucleocapsid maturation and nuclear egress. J. Virol. 2016, 90, 7109-7117. [CrossRef] [PubMed]

95. Bosse, J.B.; Enquist, L.W. The diffusive way out: Herpesviruses remodel the host nucleus, enabling capsids to access the inner nuclear membrane. Nucleus 2016, 7, 13-19. [CrossRef] [PubMed]

96. Roller, R.J.; Baines, J.D. Herpesvirus nuclear egress. Adv. Anat. Embryol. Cell Biol. 2017, 223, 143-169. [PubMed]

97. Sere, K.M.; Janssen, M.P.; Willems, G.M.; Tans, G.; Rosing, J.; Hackeng, T.M. Purified protein s contains multimeric forms with increased apc-independent anticoagulant activity. Biochemistry 2001, 40, 8852-8860. [CrossRef] [PubMed] 
98. Jorgensen, H.F.; Adie, K.; Chaubert, P.; Bird, A.P. Engineering a high-affinity methyl-cpg-binding protein. Nucleic Acids Res. 2006, 34, e96. [CrossRef] [PubMed]

99. Sethi, A.; Goldstein, B.; Gnanakaran, S. Quantifying intramolecular binding in multivalent interactions: A structure-based synergistic study on grb2-sos1 complex. PLoS Comput. Biol. 2011, 7, e1002192. [CrossRef] [PubMed]

100. Bu, J.Y.; Shaw, A.S.; Chan, A.C. Analysis of the interaction of zap-70 and syk protein-tyrosine kinases with the t-cell antigen receptor by plasmon resonance. Proc. Natl. Acad. Sci. USA 1995, 92, 5106-5110. [CrossRef] [PubMed]

101. Ramirez, J.; Poirson, J.; Foltz, C.; Chebaro, Y.; Schrapp, M.; Meyer, A.; Bonetta, A.; Forster, A.; Jacob, Y.; Masson, M.; et al. Targeting the two oncogenic functional sites of the hpv e6 oncoprotein with a high-affinity bivalent ligand. Angew. Chem. Int. Ed. Engl. 2015, 54, 7958-7962. [CrossRef] [PubMed]

102. Yamamoto, K. Assessment of weak sugar-binding ability using lectin tetramer and membrane-based glycans. Methods Mol. Biol. 2014, 1200, 413-418. [PubMed]

103. Lindborg, M.; Dubnovitsky, A.; Olesen, K.; Bjorkman, T.; Abrahmsen, L.; Feldwisch, J.; Hard, T. High-affinity binding to staphylococcal protein a by an engineered dimeric affibody molecule. Protein Eng. Des. Select. 2013, 26, 635-644. [CrossRef] [PubMed]

104. Luo, Y.; Lu, Z.; Raso, S.W.; Entrican, C.; Tangarone, B. Dimers and multimers of monoclonal igg1 exhibit higher in vitro binding affinities to fcgamma receptors. $m A b s$ 2009, 1, 491-504. [CrossRef] [PubMed]

105. Shrivastava, A.; von Wronski, M.A.; Sato, A.K.; Dransfield, D.T.; Sexton, D.; Bogdan, N.; Pillai, R.; Nanjappan, P.; Song, B.; Marinelli, E.; et al. A distinct strategy to generate high-affinity peptide binders to receptor tyrosine kinases. Protein Eng. Des. Select. 2005, 18, 417-424. [CrossRef] [PubMed]

106. Merritt, E.A.; Zhang, Z.; Pickens, J.C.; Ahn, M.; Hol, W.G.; Fan, E. Characterization and crystal structure of a high-affinity pentavalent receptor-binding inhibitor for cholera toxin and e. Coli heat-labile enterotoxin. J. Am. Chem. Soc. 2002, 124, 8818-8824. [CrossRef] [PubMed]

107. Fan, E.K.; Zhang, Z.S.; Minke, W.E.; Hou, Z.; Verlinde, C.; Hol, W.G.J. High-affinity pentavalent ligands of escherichia coli heat-labile enterotoxin by modular structure-based design. J. Am. Chem. Soc. 2000, 122, 2663-2664. [CrossRef]

108. Kochin, V.; Shimi, T.; Torvaldson, E.; Adam, S.A.; Goldman, A.; Pack, C.G.; Melo-Cardenas, J.; Imanishi, S.Y.; Goldman, R.D.; Eriksson, J.E. Interphase phosphorylation of lamin A. J. Cell Sci. 2014, 127 Pt 12, 2683-2696. [CrossRef] [PubMed]

109. Prichard, M.N. Function of human cytomegalovirus UL97 kinase in viral infection and its inhibition by maribavir. Rev. Med. Virol. 2009, 19, 215-229. [CrossRef] [PubMed]

110. Kalejta, R.F. Tegument proteins of human cytomegalovirus. Microbiol. Mol. Biol. Rev. MMBR 2008, 72, 249-265. [CrossRef] [PubMed]

(C) 2018 by the authors. Licensee MDPI, Basel, Switzerland. This article is an open access article distributed under the terms and conditions of the Creative Commons Attribution (CC BY) license (http:// creativecommons.org/licenses/by/4.0/). 